\title{
Nucleolus: the fascinating nuclear body
}

\author{
Valentina Sirri · Silvio Urcuqui-Inchima • \\ Pascal Roussel $\cdot$ Danièle Hernandez-Verdun
}

Accepted: 6 November 2007 / Published online: 29 November 2007

(C) Springer-Verlag 2007

\begin{abstract}
Nucleoli are the prominent contrasted structures of the cell nucleus. In the nucleolus, ribosomal RNAs are synthesized, processed and assembled with ribosomal proteins. RNA polymerase I synthesizes the ribosomal RNAs and this activity is cell cycle regulated. The nucleolus reveals the functional organization of the nucleus in which the compartmentation of the different steps of ribosome biogenesis is observed whereas the nucleolar machineries are in permanent exchange with the nucleoplasm and other nuclear bodies. After mitosis, nucleolar assembly is a time and space regulated process controlled by the cell cycle. In addition, by generating a large volume in the nucleus with apparently no RNA polymerase II activity, the nucleolus creates a domain of retention/sequestration of molecules normally active outside the nucleolus. Viruses interact with the nucleolus and recruit nucleolar proteins to facilitate virus replication. The nucleolus is also a sensor of stress due to the redistribution of the ribosomal proteins in the nucleoplasm by nucleolus disruption. The nucleolus plays several crucial functions in the nucleus: in addition to its function as ribosome factory of the cells it is a multifunctional nuclear domain, and nucleolar activity is linked with several pathologies. Perspectives on the evolution of this research area are proposed.
\end{abstract}

V. Sirri $\cdot$ S. Urcuqui-Inchima $\cdot$ P. Roussel .

D. Hernandez-Verdun ( $\square)$

Nuclei and Cell Cycle, CNRS, Université Paris VI,

Université Paris VII, Institut Jacques Monod,

2 place Jussieu, 75251 Paris Cedex 05, France

e-mail: daniele.hernandez-verdun@univ-paris-diderot.fr

S. Urcuqui-Inchima

Grupo de Inmunovirología, Biogénesis,

Universidad de Antioquia, Calle 62 No. 52-59,

Medellin, Colombia
Keywords Nucleolus - Cell cycle control - Assembly · Dynamics · Nucleolar structure · PNB · Virus · Cancer

\section{Introduction}

Brief history of the nucleolus

An ovoid body visible in the nucleus was probably the first observation of the nucleolus more than two centuries ago by F. Fontana. Since that time, the nucleolus has been the object of intense investigation and interestingly our vision of the nucleolus has evolved with technical progress. During the nineteenth century, using light microscopy, numerous cytologists described the variability of nucleolar morphology with great precision (Montgomery 1898). In 1934, McClintock proposed that the "nucleolus is organized in the telophase through the activity of ... the nucleolar-organizing body" (McClintock 1934). Since the nucleolar-organizing body corresponds to a specific region of chromosome 6 in Zea mays, this was the first time the nucleolus was related to gene activity. In the 1950's the presence of RNAs in the nucleolus was demonstrated, and in the 1960's in situ hybridization techniques made it possible to identify ribosomal genes (rDNAs) in the nucleolar organizer region (NOR) (Caspersson 1950; Perry 1962; Ritossa and Spiegelman 1965). During the same period, mass isolation of nucleoli became possible leading to the biochemical characterization of nucleolar components. Based on these results it was proposed that ribosome biogenesis occurs in nucleoli. Given that the nucleolus became a subject of great interest, the "International symposium on the nucleolus-its structure and function" was organized in Montevideo in 1965 and the contributions published in Natl Cancer Inst Monogr no 23 (USA) in 1966. Since 1969, at 
the initiative of W. Bernhard and H. Busch, "Nucleolar Workshops" on nucleolar organization, the biochemistry of nucleolar proteins, rRNA processing as well as variability in cancer cells were regularly organized. Several books on nucleoli were published; among them, the famous "The nucleolus and ribosome biogenesis" is still a very useful source of information (Hadjiolov 1985). Between 1980 and 2000 , the functional organization of the nucleolus was deciphered in large part due to the improvement of labeling by the electron microscopy (EM).

Recently a new field of investigation was opened when molecules not involved in ribosome biogenesis were detected in the nucleolus (Carmo-Fonseca et al. 2000; Pederson 1998; Politz et al. 2002; Visintin and Amon 2000). In accordance with these nucleolar localizations, nucleolar mass spectrometry analyses identified $\sim 700$ nucleolar proteins, some of them not related to ribosome biogenesis (Andersen et al. 2005). The area of plurifunctional nucleolus was opened. Consequently "The nucleolus", a book that presents the state of the art was published (Olson 2004) as well as several reviews on the multiple functions of the nucleolus (Boisvert et al. 2007; HernandezVerdun 2006; Hiscox 2007; Raska et al. 2006).

\section{General information}

"The nucleolus: an organelle formed by the act of building a ribosome" (Mélèse and Xue 1995) reveals by its size and organization the efficiency of ribosome biogenesis. For example the nucleolus is a prominent nuclear structure in cycling cells but of limited size in the terminal stages of differentiation such as in lymphocytes or chick erythrocytes. If ribosome biogenesis is blocked, reorganization of the nucleolar components is visible in segregated nucleoli. In mammalian cells, the nucleolus is disorganized in prophase and reassembled at the end of mitosis using the nucleolar machineries from the previous cell cycle. On the contrary, in yeast the nucleolus is present and active throughout the cell cycle even though condensation of the rDNAs is necessary for transmission of the nucleolus in anaphase (D'Amours et al. 2004; Sullivan et al. 2004; Torres-Rosell et al. 2004).

The nucleolus is the ribosome factory of the cell. In the nucleolus rDNAs are transcribed, the $47 \mathrm{~S}$ precursor ribosomal RNAs (pre-rRNAs) are cleaved, processed and assembled with the 80 ribosomal proteins and the 5S RNA to form the $40 \mathrm{~S}$ and $60 \mathrm{~S}$ ribosomal subunits (selected reviews Gébrane-Younès et al. 2005; Hernandez-Verdun and Junéra 1995; Scheer et al. 1993; Scheer and Hock 1999; Shaw and Jordan 1995; Thiry and Goessens 1996). This complex series of maturation and processing events, presently better characterized in yeast than in higher eukaryotes is under the control of about 150 small nucleolar
RNAs (snoRNAs) and 2 large RNP complexes: (1) the small subunit (SSU) processome containing the U3 snoRNAs and 40 proteins or Utps ( $U$ three proteins) required for the 40S ribosomal subunit, and (2) the large subunit (LSU) processome required for the $60 \mathrm{~S}$ ribosomal subunit (de la Cruz et al. 2004; Fatica and Tollervey 2002; FromontRacine et al. 2003; Sollner-Webb et al. 1996; Tollervey 1996). The snoRNAs associated with proteins, function in the maturation of rRNAs creating two types of modified nucleotides (2'-O-methylation and pseudouridylation) and mediating endonucleolytic cleavages of pre-rRNAs (Gerbi and Borovjagin 2004).

Our objective is to focus this review on the ribosome biogenesis processes occurring in the nucleoli that might help to decipher the global organization of nuclear functions. We describe nucleolar organization and dynamics, propose our view on nucleolar targeting, report the relationship between the nucleolus and the cell cycle, review particular relationships between nucleolus and virus, and nucleolus related to cancer.

\section{The nucleolus is a model of compartmentation}

Three main components in the active nucleolus

The nucleolus has been proposed as the paradigm of nuclear functional compartmentalization (Strouboulis and Wolffe 1996). It is the site of ribosome biogenesis and in addition the nucleolar machineries are distributed in different compartments. When observed by EM, three main nucleolar components (compartments) can be discerned in mammalian cells: the fibrillar centers (FCs), the dense fibrillar component (DFC) and the granular component (GC) (Fig. 1a). The FCs are clear areas, partly or entirely surrounded by a highly contrasted region (Goessens et al. 1987), the DFC. The FCs and the DFC are embedded in the GC, mainly composed of granules of $15-20 \mathrm{~nm}$ in diameter. The most contrasted structures in the EM sections stained with uranyl and lead correspond to high concentrations of nucleic acids. The condensed chromatin surrounding part of the nucleolus is visible using standard or preferential staining methods and also as a network within the nucleolus (Fig. 1b). The global amount of intra-nucleolar chromatin is probably low since by light microscopy, DNA staining by DAPI excludes the nucleolus.

It has become apparent that nucleoli of different cell types exhibit a variable number of FCs of different sizes, with an inverse proportion between size and number (Hozak et al. 1989; Pébusque and Seïte 1981). Generally cells with a high rate of ribosome biogenesis possess numerous small FCs. On the contrary, cells with greatly reduced metabolic and transcription activities, present 
Fig. 1 The nucleolus of mammalian cells as seen by electron microscopy. a In the human

HeLa cell, the three main nucleolar components are visible in a section of material fixed in glutaraldehyde and osmium tetroxyde, embedded in Epon and the section contrasted with uranyl acetate and lead citrate. FCs of different sizes are visible and the largest is indicated by an asterisk. The FCs are surrounded by the $D F C$ and are embedded in the $G C$. b Preferential contrast of DNA using NAMA-Ur staining in a PtK1 cell (courtesy J. Gébrane-Younès). The nucleolus is the gray structure surrounded by highly contrasted chromatin (arrow). Some chromatin filaments are also visible inside of the nucleolus $(\mathrm{Nu})$. c, $\mathbf{d}$ Nucleolus of rat neurones (courtesy M. J. Pébusque) in the day (c), and during the night (d) which is the active period for the nucleolus of the rat. In the nonactive period (c), the nucleolus is reticulated with small FCs (asterisk). In the active period, one giant FC is visible (d, asterisk). Bar in a: $0.5 \mu \mathrm{m}$ and bars in $\mathbf{b}, \mathbf{c}$ and $\mathbf{d}: 1 \mu \mathrm{m}$
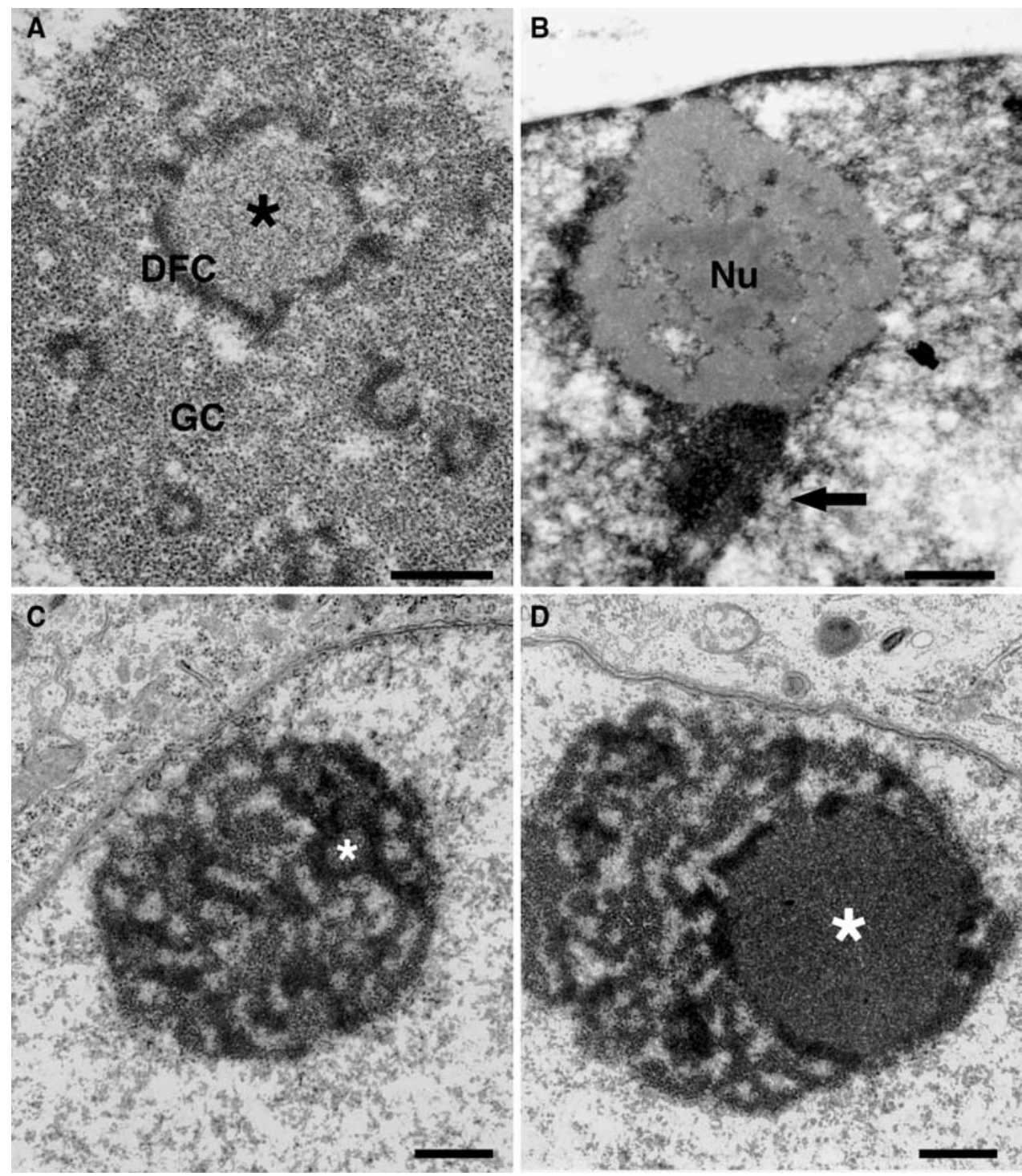

small nucleoli with one large-sized FC such as in lymphocytes and in inactive mammalian neurons (Hozàk et al. 1994; Lafarga et al. 1989). In the more active neurons, one giant FC (GFC) of 1-2 $\mu \mathrm{m}$ is observed together with small FCs (Fig. 1c, d). It was demonstrated that the GFC is enriched in the upstream binding factor, the UBF transcription factor, in a small ubiquitin-like modifier (SUMO)-1 and Ubc9 but lack ubiquitin-proteasome and $20 \mathrm{~S}$ proteasome (Casafont et al. 2007). However, the possibility that only one FC might play a role in storage and become a GFC during intense nucleolar activity is still an open question.

It is also remarkable that the tripartite nucleolar organization is not general since the nucleoli of Drosophila and insects lack FCs (Knibiehler et al. 1982; Knibiehler et al. 1984). It has been proposed that this difference in organization could be linked to the evolution of the rDNAs, in particular to the size of the intergenic sequences (Thiry and Lafontaine 2005).
The localization of the nucleolar machineries is related to their function in the production of the small and large ribosome subunits. These findings have led to assigning specific functions to specific compartments of the nucleolus. Nascent transcripts appear at the junction between the FCs and DFC and accumulate in the DFC (Cmarko et al. 2000; Guillot et al. 2005; Hozàk et al. 1994; Puvion-Dutilleul et al. 1997; Shaw and Jordan 1995). This was recently confirmed in the GFC since no transcripts can be detected in these large structures (Casafont et al. 2007). Processing of the $47 \mathrm{~S}$ pre-rRNA starts at the site of transcription in the DFC (Cmarko et al. 2000) and continues during the intranucleolar migration of the RNA towards the GC. The nucleolar proteins that participate in the early stages of rRNA processing, localize in the DFC, such as fibrillarin and nucleolin along with the U3 snoRNAs (Biggiogera et al. 1989; Ginisty et al. 1998; Ochs et al. 1985b; PuvionDutilleul et al. 1991), whereas proteins B23/NPM (nucleo- 
phosmin) and PM-Scl 100 (rrp6 in yeast) that are involved in intermediate or later stages of processing have been localized to the GC (Biggiogera et al. 1989; Gautier et al. 1994). Recent advances in the isolation of large RNP complexes by tandem affinity purification and the characterization of their constituents demonstrated that two largely independent processing machineries exist in yeast nucleoli, the SSU processome (Dragon et al. 2002; Grandi et al. 2002) and the LSU processing/assembly factors (Raué 2004). The SSU/90S processome is localized in the DFC and most of the $60 \mathrm{~S}$ processing occurs in the GC. There is no particular domain characterized in the GC corresponding to the $43 \mathrm{~S}$ subunit. This is most probably due to the limited events of $40 \mathrm{~S}$ processing in the GC since the last step of processing occurs in the cytoplasm. In conclusion it seems that in the nucleoli, the vectorial distribution of the machineries successively involved in ribosome biogenesis correlates with the different processing steps of the biogenesis of the ribosome subunits.

When ribosome biogenesis is active, the confinement of certain machineries in the FCs, DFC or GC makes it possible to reveal these subnucleolar constituents by immunofluorescence as illustrated for FCs (Fig. 2A), DFC (Fig. 2Ba, b), and GC (Fig. 2Bc, d). The factors associated with the rDNA transcription machinery are distributed in several foci, most frequently inside the nucleolar volume as illus- trated for UBF. These foci correspond to FCs. A distribution within the network inside the nucleolus is typical of the DFC as demonstrated for fibrillarin. Labeling of the nucleolar volume excluding small areas contained within the volume is typical of the GC as illustrated for B23/NPM. These labeling patterns (FCs, DFC, GC) in the nucleoli provide a good indication of the step of ribosome biogenesis concerned and also reveal the blockage of ribosome biogenesis when this organization is disturbed (see below).

Signature of impaired ribosome biogenesis

Transient association of functionally related components appears necessary to generate a morphologically defined nucleolus with its three distinct components, thereby maintaining the nucleolus in its usual organization. This suggests that such an organization results from the activity of ribosome biogenesis. Indeed nucleolar reorganization is induced when ribosome biogenesis is impaired either by inhibiting rDNA transcription, or inhibiting rRNA processing and/or transport.

\section{Inhibition of transcription}

Nucleolar segregation is observed upon rDNA transcriptional arrest either in physiological conditions or induced
Fig. 2 The subnucleolar constituents revealed by fluorescence microscopy. (A) The rDNA transcription machinery, illustrated by $U B F$ labeling, is localized in several foci corresponding to FCs in HeLa cells (a). rDNA transcription sites detected by in situ BrUTP incorporation $(b)$, mainly colocalize with $U B F$ as seen by the merge (c). The nucleus is visualized by Dapi staining (d). (B) HeLa cells expressing either fibrillarinGFP fusion or DsRed-B23 fusion. Fibrillarin decorates the $\operatorname{DFC}(a, b)$ whereas B23 decorates the GC $(c, d)$. In $A c t D$ treated cells nucleoli are segregated, fibrillarin localizes in caps $(e, f)$ contrary to B23 that localizes in the central body and outside the caps $(g, h)$. Arrowheads point the caps. Bars: $10 \mu \mathrm{m}$
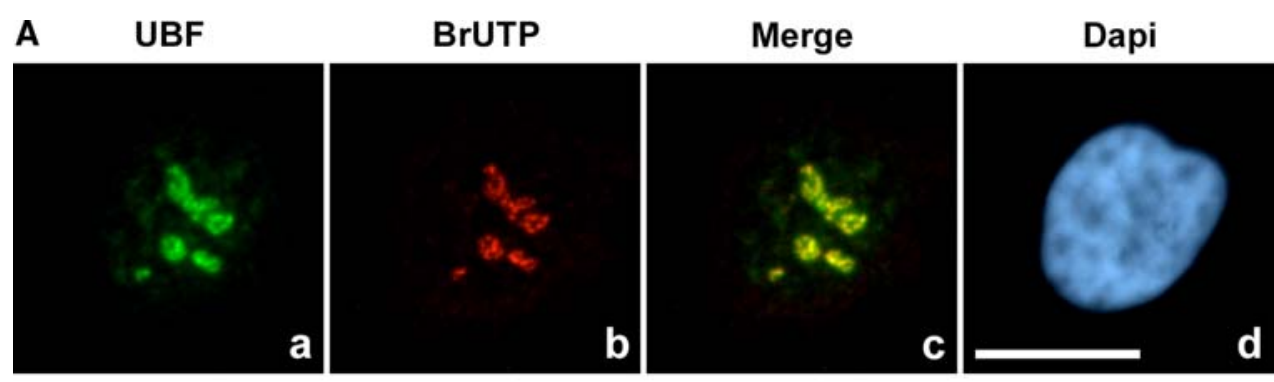

B

- ActD
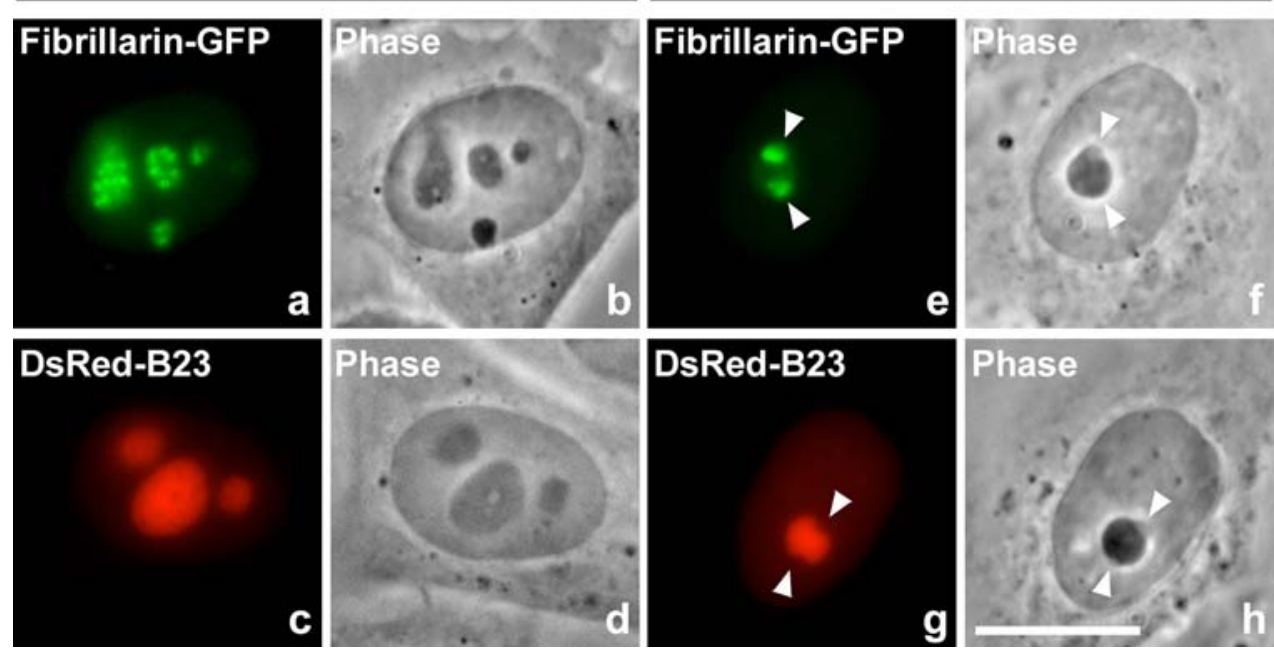
by low doses of actinomycin $\mathrm{D}$ (ActD). The segregation of nucleoli is characterized by the separation of the nucleolar components that remain close to each other but no longer intermingle (Fig. 2Be-h) (for reviews see Hadjiolov 1985; Hernandez-Verdun and Junéra 1995; Scheer and Benavente 1990). The effect of ActD on nucleolar organization follows sequential changes: first the fibrillar components (FCs and DFC) condense and migrate towards the periphery of the nucleolus, after which the nucleolar components segregate to finally form a central body associated with caps (Hadjiolova et al. 1995). In the caps are several proteins related to the RNA polymerase (pol) I transcription machinery such as UBF, close to fibrillarin-containing caps. In the central body are proteins derived from the GC, some of which are progressively released, such as PM-Scl 100. It was recently demonstrated that certain nucleolar caps of segregated nucleoli could recruit factors involved in mRNA splicing. In this case, localization is induced by inhibition of both RNA pol I (rRNA transcription arrest) and RNA pol II (mRNA transcription arrest) (Shav-Tal et al. 2005). This is not observed when only RNA pol I is inhibited indicating that the composition of a segregated nucleolus can be more complex when induced by general transcription inhibition.

One question that remains unanswered is how nucleolar components continue to be maintained in segregated nucleoli in spite of the absence of transcription or pre-rRNA processing. Nucleolar proteins may still be capable of forming complexes during inhibition of transcription, but why these complexes remain juxtaposed is presently unknown. Recently, it was reported that re-localization of proteins in specific caps of segregated nucleoli (after inhibition of RNA pol I and II transcription) is an energy-dependent repositioning process that requires active metabolism of the cells (Shav-Tal et al. 2005) most probably also ATP and GTP.

\section{Degradation of rRNAs}

A clue to the question of rRNA degradation in the nucleolus was recently proposed in yeast: a surveillance pathway that eliminates defective $60 \mathrm{~S}$ pre-ribosomal subunits after addition of poly(A) tails was described (LaCava et al. 2005). RNA degradation appears to occur preferentially within a subnucleolar structure, the No-body, and is mediated by the exosome (Dez et al. 2006). Similarly, when the nuclear protein of the exosome rrp6 was deleted, poly(A) rRNAs and poly(A) U14 snoRNAs colocalized in one focus with Nop1 (fibrillarin in human), most probably the Nobody (Carneiro et al. 2007). This body is distinct from the nucleolar body that functions in snoRNA maturation in yeast and could be a compartment where polyadenylation and degradation of nucleolar RNAs take place. This compartmentation would promote efficient recognition of
rRNAs in view of degradation by the exosome (Carneiro et al. 2007). During nucleolar segregation induced by ActD in human cells, rRNAs are degraded. However, the formation of one focus containing PM-Scl 100 has not been described; it could be either an early event that was not carefully examined, or rRNA degradation could be different in yeast and mammalian cells.

\section{Disconnection of the nucleolar component}

Disconnection between rDNA transcription sites and the late rRNA processing proteins can be induced either by kinase inhibitors or by modifications of snoRNA domains (Chan et al. 1996; Colau et al. 2004; David-Pfeuty et al. 2001; Rubbi and Milner 2003; Sirri et al. 2002). The separation of the DFC and GC can be reversed by removal of a CK2 inhibitor, restoring nucleolar organization. The CK2 kinase is known to phosphorylate several nucleolar proteins (Meggio and Pinna 2003). We postulate that the connection between DFC and GC is controlled at least in part by phosphorylation of these proteins. This hypothesis was verified for B23 by mutation of the major site of CK2 phosphorylation (Louvet et al. 2006). In conclusion, the rRNA processing proteins can be disconnected from the rRNA transcription sites indicating that rRNA transcripts are not sufficient to attract the processing proteins in these conditions. The dynamics of nucleolar reformation and the connection between DFC and GC is ATP/GTP dependent, sensitive to temperature, and is CK2-driven.

\section{Traffic and dynamics of nucleolar actors}

The analysis in living cells of intranuclear dynamics has recently become possible using fluorescent fusion proteins. Time-lapse videomicroscopy can track the movement of large fluorescent complexes in the cell, and fluorescent recovery after photobleaching (FRAP) can measure the intracellular mobility or the residency time of fluorescent proteins (Lippincott-Schwartz et al. 2001). Inverse FRAP (iFRAP) quantifies the loss of fluorescence of the region of interest (ROI) after complete bleaching outside this region (Dundr et al. 2004). This constitutes a direct evaluation of the residency time of the proteins in the ROI. Another approach is the use of photoactivatable GFP (PA-GFP) to follow the traffic of the activated proteins (Patterson and Lippincott-Schwartz 2002). This process is similar to pulsechase experiments since it makes it possible to follow a pool of labeled proteins starting at time zero. These technologies applied to nuclear dynamics have introduced new dimensions and unexpected concepts concerning nuclear functional compartmentation. The mobility of several GFPtagged nuclear proteins (nucleolar proteins, histones, DNA 
binding proteins, transcription factors, splicing factors, nuclear receptors) has been estimated by FRAP and the recovery of fluorescence was slower than predicted for isolated diffusing proteins of similar size. FRAP recovery rates change with inhibition of transcription, decreased temperature and depletion of ATP indicating that recovery is correlated with nuclear activity.

It was demonstrated that nucleolar proteins rapidly associate with and dissociate from nucleolar components in continuous exchanges with the nucleoplasm (Phair and Misteli 2000). The recovery curve of GFP-fibrillarin (DFC marker) in the nucleolus reached a plateau, $60 \mathrm{~s}$ after bleaching and the plateau indicated an immobile fraction of $\sim 15 \%$. The diffusion coefficient of fibrillarin (estimated between 0.02 and $0.046 \mu \mathrm{m}^{2} \mathrm{~s}^{-1}$ ) was 10 times lower in the nucleolus than in the nucleoplasm (Chen and Huang 2001; Phair and Misteli 2000; Snaar et al. 2000). This value is proposed to reflect the time of residency of fibrillarin engaged in nucleolar activity, and could explain the fact that the time of residency of fibrillarin is shorter in the Cajal body than in the nucleolus (Dundr et al. 2004). The nucleolar proteins engaged in rRNA transcription and processing (respectively UBF, B23, Nop52, nucleolin and Rpp29) also move with rapid recovery rates in the nucleolus as does fibrillarin (Chen and Huang 2001; Louvet et al. 2005). Conversely the recovery rates of ribosomal proteins are slow ( $\sim 3$ times slower than nucleolar proteins). This could reflect a slower mechanism for ribosome protein assembly compared with transcription and processing (Chen and Huang 2001), or alternatively, more stable associations of ribosomal proteins with the pre-rRNAs.

B23 (also designated NPM) is a multifunctional protein, abundant in the GC of the nucleolus that undergoes different phosphorylation events during the cell cycle. It was recently demonstrated by FRAP that the kinetics of B23 depends on its phosphorylation status (Negi and Olson 2006). During interphase, the half-time $\left(t_{1 / 2}\right)$ recovery of B23 is $22 \mathrm{~s}$ in nucleoli but when the CK2 phosphorylation site is mutated (S125A) the $t_{1 / 2}$ increases to $44 \mathrm{~s}$, and when a mutant mimicking phosphorylation charges of the four sites of mitotic CDK1 phosphorylation, the $t_{1 / 2}$ decreases to $12 \mathrm{~s}$. This could indicate that the S125A-B23 protein has a higher affinity for the nucleolar components (Negi and Olson 2006). Alternatively this could correspond to a decreased turner-over in the nucleolar complexes in correlation with the disconnection of the DFC and GC occurring by overexpression of S125A-B23 (Louvet et al. 2006). Overexpression during interphase of B23 mimicking four sites of mitotic phosphorylation increased the mobility of B23. It is tempting to propose that this results from a defect of affinity for rRNAs of these B23s as demonstrated for mitotic phosphorylation of B23 (Okuwaki et al. 2002).
Inhibition of pol I transcription by ActD does not prevent traffic of nucleolar proteins. However, if the diffusion coefficient of nucleolar proteins in the nucleoplasm is similar for active and repressed pol I transcription, the traffic in segregated nucleoli changes differently for different nucleolar components. Traffic of UBF in the nucleolus is decreased by ActD, whereas it is similar for nucleolin or increased for ribosomal proteins (Chen and Huang 2001).

In contrast to the well-defined nucleolar structures visible by EM, all the nucleolar proteins involved in ribosome biogenesis that have been examined, cycle between the nucleolus and the nucleoplasm in interphase cells. To summarize, it is now established that rapid diffusion of nucleolar proteins occurs in the nucleoplasm and recruitment to the nucleolus is permanent. Moreover, the difference in kinetics of several proteins shared between the nucleolus and the Cajal body suggests the existence of compartmentspecific retention (Dundr et al. 2004).

\section{Targeting to the nucleolus}

To be localized or retained within the nucleolus

In eukaryotic cells, once imported or diffused into the nucleus, some proteins distribute throughout the nucleoplasm and others are targeted to specific nuclear compartments such as nucleoli. Proteomic analyses revealed that at least 700 proteins are localized in nucleoli (Andersen et al. 2002, 2005; Leung et al. 2003). Whereas the rules and signals that govern the nuclear localization and nuclear export of proteins are now well defined, those concerning nucleolar localization are still debated.

Contrary to the nuclear localization signals (NLSs), nucleolar localization signals or sequences (NoLSs) are not well characterized. Although several NoLSs have been described, no obvious consensus sequence has emerged. Nevertheless all NoLSs reported for nucleolus localizing virus proteins, such as HIV-1 Rev (Kubota et al. 1989), HIV-1 Tat (Dang and Lee 1989) and human T-cell leukaemia virus type 1 Rex (HTLV-1 Rex) (Siomi et al. 1988), and for cellular proteins such as the nucleolar protein 120 (Valdez et al. 1994), Survivin-deltaEx3 (Song and Wu 2005) and HSP70 (Dang and Lee 1989) are rich in basic residues. The capacity of numerous proteins to adopt nucleolar localization has been correlated with interaction of these proteins with B23. Owing to the ability of numerous nucleolar proteins to interact with B23 and because this major nucleolar protein shuttles constantly between the nucleus and the cytoplasm (Borer et al. 1989), it was frequently suggested that B23 might be a transporter for nucleolar proteins possessing a NoLS (Fankhauser et al. 1991; Li 1997; Valdez et al. 1994). Even if this tempting 
hypothesis has never been demonstrated, recent results obtained using stable U2OS-derived cell lines with reduced B23 expression levels showed that the nucleolar localization of ARF is linked to B23 (Korgaonkar et al. 2005). Indeed, reduced expression of B23 induced a partial delocalization of ARF from nucleoli to nucleoplasm. The authors therefore concluded that B23 targets ARF to nucleoli in a dose-dependent manner. Nevertheless, this result does not allow discriminating between a role for B23 in the transport of ARF from nucleoplasm to nucleoli and/or in the retention of ARF in nucleoli.

A NoLS, i.e. a sequence essential for nucleolar localization, is most probably a sequence involved in nucleolar retention by interacting with a nucleolar molecule such as B23 (Lechertier et al. 2007). Indeed, recent analyses of the intranuclear dynamics of proteins in living cells revealed that nuclear proteins could diffuse within the nucleoplasm (Phair and Misteli 2000; Sprague and McNally 2005). As for the nucleolus, it was demonstrated that nucleolar proteins rapidly associate with and dissociate from nucleolar components in a continuous exchange with the nucleoplasm (Chen and Huang 2001; Dundr et al. 2004; Phair and Misteli 2000; Snaar et al. 2000). There probably exist compartment-specific retention mechanisms for proteins in nuclear bodies, implying that the residency time of a particular molecule in a given nuclear body depends on its specific interactions (Misteli 2001). In support of this possibility, we have recently shown that the fusion of a B23-interacting sequence with fibrillarin makes it possible to re-localize fibrillarin from the DFC to the GC of nucleoli where B23 is mainly localized (Lechertier et al. 2007). Similarly, by fusing the B23-interacting sequence to MafG (part of the nuclear transcription factor NF-E2 composed of both MafG and p45), NF-E2 is redirected from the nucleoplasm to the GC. Therefore, interactions most probably govern the nuclear distribution of proteins and a NoLS is very likely a nucleolar molecule-interacting sequence.

However, nucleolar localization of a protein is most probably governed by several factors and the presence of a NoLS in its sequence is not sufficient to predict nucleolar localization of the protein. In particular, a nucleolar protein must first be localized in the nucleus, and consequently all mechanisms that interfere with nuclear import and/or nuclear export of a nucleolar protein will modify its localization at the steady state. A good illustration is provided by the major nucleolar protein, B23. This multifunctional protein is normally mainly located in the GC of nucleoli but exhibits an aberrant cytoplasmic localization in one-third of acute myeloid leukemias due to mutations in its $\mathrm{C}$-terminal coding exon that causes a frameshift and the formation of an additional CRM1-dependent nuclear export signal (NES) (Mariano et al. 2006). Another example showing the difficulty encountered in predicting nucleolar localization is provided by the box C/D snoRNPs: it seems clear that the nucleolar localization of box C/D snoRNPs is linked to their biogenesis (Verheggen et al. 2001; Watkins et al. 2002). Indeed, by modifying the conserved stem II of the box C/D motif present in the U14 snoRNA, both the specific assembly of the box C/D snoRNP and nucleolar localization are lost (Watkins et al. 2002). Moreover, genetic depletion of one of the four core proteins, namely $15.5 \mathrm{kD}$, Nop56, Nop58 and fibrillarin, also inhibits the nucleolar localization of box C/D snoRNPs (Verheggen et al. 2001). However, targeting of box C/D snoRNPs to nucleoli is not yet fully understood. Indeed, unexpectedly two nuclear export factors, PHAX and CRM1 appear to be stably associated with the U3 pre-snoRNPs (Boulon et al. 2004; Watkins et al. 2004). Boulon and coworkers proposed that U3 precursors bind PHAX, which targets the complex to the Cajal body, and that subsequently CRM1 further targets the U3 complexes to the nucleolus. Even if PHAX and CRM1 play an important role in the transport of box C/D snoRNPs to the nucleus, the possibility that these proteins may also function in the nuclear export of snoRNPs cannot be excluded (Watkins et al. 2004). This possibility is reinforced by a recent study showing that in addition to nuclear export factors, the nuclear import factor Snurportin 1 is involved in U8 box C/D snoRNP biogenesis (Watkins et al. 2007). Nucleolar localization of the components of the box C/D snoRNPs would therefore depend on the biogenesis of the box C/D snoRNP complexes, which would imply nuclear export.

\section{Control of rDNA transcription during cell cycle}

\section{rDNA transcription machinery}

rDNAs are found in multiple, tandem, head-to-tail arrayed copies in the nucleoli of eukaryotic cells (Hadjiolov 1985). In mitotic human cells, rDNA clusters are localized on the short arm of the five pairs of chromosomes 13, 14, 15, 21 and 22 and are termed NORs. Each rDNA unit consists of a transcribed sequence and an external non-transcribed spacer (Hadjiolov 1985; Liau and Perry 1969) in which all the sequences necessary for proper RNA pol I transcription such as proximal promoters, spacer promoters and terminators are located (Hadjiolov 1985). In the rDNA promoter two important elements have been described, a CORE element and an upstream control element (UCE) (Haltiner et al. 1986; Windle and Sollner-Webb 1986; Xie et al. 1992) that function synergistically to recruit a transcriptionally competent RNA pol I complex. This complex contains in addition to RNA pol I, the upstream binding factor (UBF) (Pikaard et al. 1989; Voit et al. 1992), the selectivity factor protein complex SL1 (Learned et al. 1985) also 
called TIF-1B in mouse cells (Clos et al. 1986), consisting of the TATA-binding protein (TBP) and four transcription activating factors $\left[\mathrm{TAF}_{\mathrm{I}} \mathrm{s} 110,63,48\right.$ and 41 (Comai et al. 1994; Gorski et al. 2007; Zomerdijk et al. 1994)], the transcription initiation factor TIF-IA, the mouse homolog of Rrn3p (Bodem et al. 2000; Moorefield et al. 2000) and the transcription termination factor TTF-1 (Bartsch et al. 1988). The UBF containing HMG boxes (Bachvarov and Moss 1991; Jantzen et al. 1990) that confer a high affinity for DNA structures plays an architectural role on the rDNA promoter (Mais et al. 2005). It was proposed that UBF activates rDNA transcription because it stabilizes binding of SL1 required to recruit the initiation-competent subfraction of RNA pol I. This recruitment is achieved by interaction of UBF with the RNA pol I-associated factor PAF53 (Schnapp et al. 1994), and by interaction of SL1 with TIF-1A/ Rrn3p (Miller et al. 2001). TIF-1A/Rrn3p interacts also with the RPA43 subunit of RNA pol I and thus facilitates linking between RNA pol I and SL1 complexes (Peyroche et al. 2000; Yuan et al. 2002). Following initiation, TIF-1A/ Rrn3p is released and can associate with another preinitiation complex. Recycling of TIF-1A/Rrn3p requires a posttranslational phosphorylation event that appears to play a role in its initiation activity (Cavanaugh et al. 2002; Zhao et al. 2003). Moreover, it was proposed that TTF-1 is not only involved in termination of transcription in cooperation with the release factor PTRF (Jansa and Grummt 1999), but also in the remodeling of ribosomal chromatin by recruiting ATP-dependent remodeling factors to the rDNA promoter (Längst et al. 1997). The nucleolar remodeling complex (NoRC) (Strohner et al. 2001), which acts in repression at the rDNA promoter level ( $\mathrm{Li}$ et al. 2006; Santoro et al. 2002), and the transcription activator CSB (Cockayne syndrome group B protein), a DNA-dependent ATPase, interact with TTF-1 (Yuan et al. 2007). The finding that TTF-1 interacts with both CSB and NoRC suggests that competitive recruitment of CSB and NoRC may determine the epigenetic state of the rDNA.

Regulation during the cell cycle

It is now established that the presence of a fully active nucleolus depends on cell cycle regulators. rDNA transcription is maximum in the $\mathrm{S}$ and $\mathrm{G} 2$ phases, silent in mitosis, and slowly recovers in G1. Post-translational modifications of the RNA pol I machinery are required for the formation of a productive preinitiation complex. The phosphorylation status of several components of the RNA pol I machinery can modify the activity and interactions of these proteins and thus can modulate rDNA transcription during the cell cycle. Concerning silencing of rDNA transcription during mitosis, it is well established that some components of the rDNA transcription machinery such as SL1 (Heix et al. 1998) and TTF-1 (Sirri et al. 1999), are mitotically phosphorylated by CDK1-cyclin B. As shown in vitro, CDK1-cyclin B-mediated phosphorylation of SL1 abrogates its transcriptional activity (Heix et al. 1998). Moreover CDK1-cyclin B is necessary not only to establish repression but also to maintain it from prophase to telophase. Indeed, in vivo inhibition of CDK1-cyclin B leads to dephosphorylation of the mitotically phosphorylated forms of components of the RNA pol I machinery and restores rDNA transcription in mitotic cells (Sirri et al. 2000). On the other hand, rDNA transcription also appears regulated by $\mathrm{CDK}(\mathrm{s})$ during interphase: the increase of rDNA transcription during G1 progression depends on phosphorylation of UBF by G1-specific CDK-cyclin complexes (Voit et al. 1999), and CDK inhibitor treatments partially inhibit rDNA transcription in interphase cells (Sirri et al. 2000). Modifications of the phosphorylation status of UBF and/or $\mathrm{TAF}_{\mathrm{I}} 110$ affect the interactions between UBF and SL1 necessary for recruitment of RNA pol I (Zhai and Comai 1999). In addition to phosphorylation, it has been speculated that acetyltransferases might also regulate the activity of RNA pol I transcription factors. Indeed, two studies have demonstrated that UBF and one of the SL1 subunits are acetylated in vivo (Muth et al. 2001; Pelletier et al. 2000). Functional studies indicated that acetylated UBF is transcriptionally more active than deacetylated UBF. However, acetylation of UBF does not affect its DNA binding activity as shown for other transcription factors, and it is unclear how this post-transcriptional modification modulates UBF activity. The $\mathrm{TAF}_{\mathrm{I}} 68$ subunit of SL1 is specifically acetylated by recruitment of PCAF (p300/CBP associated factor) to the rDNA promoter. In vitro analyses indicate that acetylation of $\mathrm{TAF}_{\mathrm{I}} 68$ is likely to increase the activity of SL1 facilitating interaction of the complex with DNA. Sirtuins, the human homologues of the yeast Sir2 (silent information regulator) with NAD-dependent deacetylase and ADP-ribosyltranferase activity, have recently been implicated in the regulation of the RNA pol I machinery. In particular, nuclear sirtuin1 deacetylates $\mathrm{TAF}_{\mathrm{I}} 68$ and represses RNA pol I transcription in vitro (Muth et al. 2001). Conversely, the nucleolar sirtuin7 is described as activator of rDNA transcription by increasing RNA pol I recruitment to the rDNA, but no substrates of such activity have as yet been identified (Ford et al. 2006). Additional in vivo approaches are necessary to better understand the role of sirtuins in the regulation of rDNA transcription.

SUMO modification is reported to influence the assembly of transcription factors on promoters and the recruitment of chromatin-modifying enzymes, and is often associated with transcriptional repression (Gill 2004). Recently, the colocalization of SUMO-1 and UBF in the GFC (Casafont et al. 2007) of neuronal cells and the nucle- 
olar localization of the sentrin/SUMO-specific proteases, SENP3 and SENP5 (Gong and Yeh 2006; Nishida et al. 2000) suggest a potential role of sumoylation on the regulation of rDNA transcription. Further studies of the identification of sumoylated nucleolar transcription factors will be necessary to verify this possibility.

\section{Nucleolar assembly and disassembly}

In higher eukaryotic cells at the beginning of mitosis when rDNA transcription is repressed, the nucleoli disassemble and are no longer observed throughout mitosis. Conversely nucleoli assemble at the exit from mitosis concomitantly with restoration of rDNA transcription and are functionally active throughout interphase.

\section{Disassembly in prophase}

In late prophase when mitotic repression of rDNA transcription occurs, the rDNA transcription machinery remains associated with rDNAs in the NORs as revealed by the analysis of different components at the steady state (Roussel et al. 1993, 1996; Sirri et al. 1999). Nevertheless, more recent quantitative kinetic analyses have revealed that some RNA pol I subunits, including RPA39, RPA16 and RPA194, transiently dissociate from the NORs during metaphase and reappear in anaphase (Chen et al. 2005; Leung et al. 2004). As for the mechanism that governs disassembly of nucleoli in prophase, it may be assumed that it is linked to repression of rDNA transcription, most probably caused by CDK1-cyclin B-directed phosphorylation of components of the rDNA transcription machinery (Heix et al. 1998; Sirri et al. 1999).

At the beginning of prophase, the components of the prerRNA processing machinery do not remain in the vicinity of the rDNAs (Gautier et al. 1992) but become partially distributed over the surface of all the chromosomes (reviewed in Hernandez-Verdun et al. 1993). The nucleolar proteins that relocate to the chromosome periphery are components of the DFC and GC of the active nucleolus. In living cells, nucleolar proteins tagged with GFP are concentrated around the chromosomes during mitosis and migrate with the chromosomes (Savino et al. 2001). However, the mechanisms maintaining interactions of nucleolar processing proteins with chromosomes during mitosis have not been characterized. The colocalization of the different factors involved in pre-rRNA processing suggests that processing complexes are at least to some extent maintained during mitosis. It is as yet unknown whether migration of the nucleolar processing proteins occurring at the onset of mitosis (Fan and Penman 1971) takes place as a consequence of the arrest of pre-rRNA synthesis or whether it is also regulated. Indeed, it is noticeable that (1) during prophase, the components of the rRNA processing machinery appear to be delocalized before total repression of rDNA transcription occurs, and (2) the most recently synthesized pre-rRNAs accumulate as partially processed $45 \mathrm{~S}$ prerRNAs (Dousset et al. 2000) suggesting that total repression of pre-rRNA processing could occur prior to total repression of rDNA transcription. These observations therefore raise the possibility that rDNA transcription and pre-rRNA processing are both repressed during prophase by distinct mechanisms.

Assembly in telophase

Nucleoli assemble at the exit from mitosis concomitantly with restoration of rDNA transcription at the level of competent NORs (Roussel et al. 1996). Until recently it was admitted that transcriptionally active rDNAs, serving as nucleation sites, possessed by themselves the ability to organize the nucleoli (Scheer and Weisenberger 1994). Results obtained in the laboratory showed that (1) reactivation of rDNA transcription in mitotic cells does not lead to the formation of nucleoli (Sirri et al. 2000), (2) initiation of nucleolar assembly occurs independently of rDNA transcription (Dousset et al. 2000), and (3) at the exit from mitosis nucleologenesis is impaired in the presence of a CDK inhibitor even if rDNAs are actively transcribed (Sirri et al. 2002). Consequently, the formation of functional nucleoli at the exit from mitosis is not governed solely by the resumption of rDNA transcription. Based on previous studies (Sirri et al. 2000, 2002), we propose that the formation of nucleoli is a process regulated by $\mathrm{CDK}$ (s) at two levels: resumption of rDNA transcription but also restoration of rRNA processing.

In anaphase, early and late processing proteins (respectively fibrillarin, and Bop1, B23, Nop52) are homogeneously distributed around the chromosomes. During telophase and early G1, along the translocation pathway between chromosome periphery and transcription sites, processing proteins concentrate in foci designated prenucleolar bodies (PNBs), first described in plant cells (Stevens 1965). PNB formation is a general phenomenon occurring during the recruitment of the nucleolar processing proteins at exit from mitosis (Angelier et al. 2005; Azum-Gélade et al. 1994; Dundr et al. 2000; Jiménez-Garcia et al. 1994; Ochs et al. 1985a; Savino et al. 2001). This appears to be a cell cycle regulated process since when the nucleolar function is established during interphase, recruitment of processing proteins is not associated with PNB formation. Inactivation of CDK1-cyclin B occurring at the end of mitosis induces the first events of nucleologenesis. Strikingly, fibrillarin concentrates in PNBs and rDNA clusters when decrease in CDK1-cyclin B activity overcomes the mitotic repression 
of RNA pol I transcription (Clute and Pines 1999), while Nop52 and other GC proteins are recruited later on transcription sites. This late recruitment is under the control of cyclin-dependent kinases since CDK inhibitors block this process (Sirri et al. 2002). Thus, it seems that recruitment of the processing machinery at the time of nucleolar assembly is a regulated process most probably dependent on cell cycle progression. This provides a physiological situation to investigate the formation, control and dynamics of nuclear bodies.

The dynamics of the processing nucleolar proteins was analyzed at the transition mitosis/interphase using rapid time-lapse video microscopy (Fig. 3). The first detectable assembly of proteins in foci occurred on the surface of the chromosome during telophase (Savino et al. 2001), followed by the progressive delivery of proteins to nucleoli ensured by progressive and sequential release of proteins from PNBs (Dundr et al. 2000). Based on the observations of different fixed cells, it was concluded that the early processing proteins are recruited first on transcription sites while the majority of the late processing proteins are still in PNBs (Fomproix et al. 1998; Savino et al. 1999). This sequence of events was confirmed in living HeLa cells. Fibrillarin resides briefly in PNBs $(\sim 15 \mathrm{~min})$ before recruitment to the nucleolus, while Nop52 is maintained longer in PNBs ( $\sim 80 \mathrm{~min})$ (Savino et al. 2001). The relative dynamics of early and late rRNA processing proteins at the time of PNB formation was examined using coexpression of GFP-fibrillarin and DsRed-B23 (Angelier et al. 2005). Once near the poles, 1-2 min after the onset of telophase, numerous bright fluorescent foci containing both GFP-fibrillarin and DsRed-B23 appeared almost simultaneously. For about $10 \mathrm{~min}$, the relative amount of B23 in foci was five to six times higher than that of the dispersed proteins whereas the amount of fibrillarin in the same foci was three to four times higher than that of dispersed proteins. Subsequently, fibrillarin was released while B23 was still present in the foci. This clearly illustrates the presence of the two types of nucleolar processing proteins in the same PNBs and suggests differential sorting of these proteins. Conversely in the same conditions, simi- lar dynamics and flows of GFP-Nop52 and DsRed-B23 were observed. Thus the processing proteins passed through the same PNBs and were released simultaneously suggesting that these proteins could form complexes in PNBs.

Time-lapse analysis of fluorescence resonance energy transfer (FRET) was chosen to determine whether nucleolar processing proteins interact along the recruitment pathway. The apparatus used to determine FRET performs tdFLIM (time domain fluorescence lifetime imaging microscopy) by the time and space-correlated single-photon counting method (Emiliani et al. 2003). This technique directly yields the picosecond time-resolved fluorescence decay for every pixel by counting and sampling single emitted photons. Positive FRET between GFP-Nop52 and DsRed-B23 in nucleoli indicates that the distance and most probably the interactions between the proteins can be evaluated by this approach (Angelier et al. 2005). Since it is possible to detect FRET between B23 and Nop52 in nucleoli, FRET was tracked during the recruitment of these proteins into nucleoli from anaphase to early G1. FRET was never detected during anaphase at the periphery of the chromosomes whereas it was registered in $20 \%$ of the PNBs at the beginning of telophase, in about $40 \%$ at the end of telophase, and in $55 \%$ in early G1. Thus, interaction between GFP-Nop52 and DsRed-B23 was established progressively in PNBs, as the number of PNBs exhibiting FRET increased. Such data indicate that Nop52 and B23 did not interact until they were recruited in PNBs. It is noteworthy that a given PNB can alternatively present or not present FRET. Based on the behavior of these two proteins, one possibility is that late rRNA processing proteins already interact in PNBs. Were this to be confirmed for other rRNA processing complexes, PNBs could be proposed as assembly platforms of processing complexes at this step of the cell cycle. It would be very interesting to establish whether this role can be extended to the early rRNA processing machinery (Angelier et al. 2005).

In conclusion, assembly of the nucleolus requires reactivation of the rDNA transcription machinery, and also recruitment and reactivation of the pre-rRNA processing
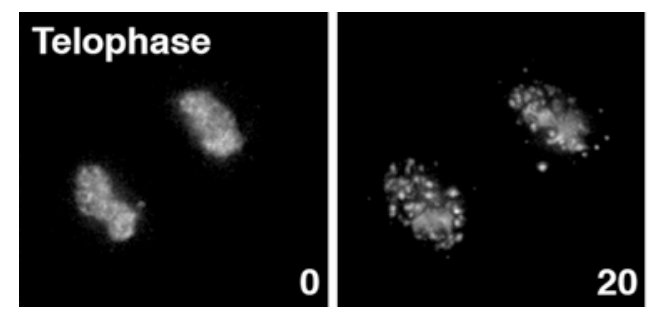

Fig. 3 At the exit from mitosis, the dynamics of DsRed-B23 is followed in living cell. In telophase $(0 \mathrm{~min})$, the B23 signal is visible in small foci. These foci corresponding to PNBs are clearly visible

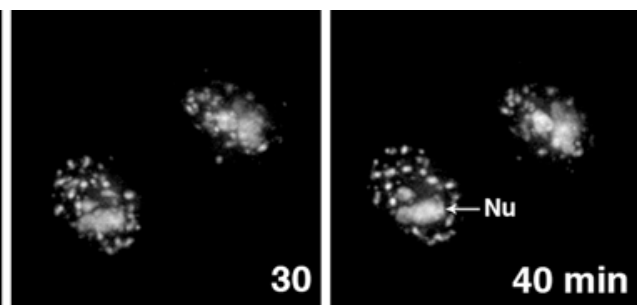

20 min later. The B23-containing PNBs are distributed in the nucleoplasm and B23 is progressively recruited in the incipient nucleolus (40 min). $N u$ nucleolus 
machinery. Indeed cells exiting from mitosis in the presence of a CDK inhibitor exhibit neither relocalization of the late pre-rRNA processing components from PNBs to rDNA transcription sites, resumption of proper rRNA processing, nor formation of functional nucleoli.

\section{Nucleolus and cancer}

The link between cell proliferation, cancer and nucleolar activity has been well established during the past several decades (more than 5,000 references). Half of the studies related to the nucleolus and cancer are dedicated to the prognostic value of AgNOR staining, a technique revealing the amount of nucleolar proteins. The aim of this technique is to evaluate the proliferation potential of cancer cells by measuring nucleolar activity. B23, nucleolin, UBF and subunits of RNA pol I were found to be the argyrophilic proteins responsible for the silver-staining properties of nucleolar structures (Roussel et al. 1992; Roussel and Hernandez-Verdun 1994). In interphase cells, the amount of major AgNOR proteins, B23 and nucleolin, is high in $\mathrm{S}-\mathrm{G}_{2}$ and low in $G_{1}$ phases and thus a higher value of AgNOR corresponds to actively cycling cells (Sirri et al. 1997). Standardization of the AgNOR staining method permits routine application of this technique for clinical purposes. The size of the nucleolus is generally enlarged in cancer cells, and this has been correlated with cell proliferation.

A new field of research was recently opened by the discovery that several tumor suppressors and proto-oncogenes affect the production of ribosomes (Ruggero and Pandolfi 2003). rRNA synthesis is enhanced by c-Myc (Arabi et al. 2005) and it was proposed that this stimulation is a key pathway driving cell growth and tumorigenesis (Grandori et al. 2005). On the contrary, the decrease of ribosome production induces apoptosis in a p53-dependent or independent manner (David-Pfeuty et al. 2001; Pestov et al. 2001) and the disruption of the nucleolus mediates p53 stabilization (Rubbi and Milner 2003). The cross talk between the p53 pathway and the nucleolus is at least in part mediated by localization of Mdm2 in the nucleolus, an E3 ubiquitin ligase involved in p53 degradation. Nucleostemin, a nucleolar protein discovered in stem cells and in cancer cells interacts with p53 (Tsai and McKay 2005, 2002). It was proposed that nucleostemin might regulate p53 function through shuttling between the nucleolus and the nucleoplasm. The major nucleolar protein B23 is directly implicated in cancer pathogenesis as demonstrated by mutation of the gene in a number of hematological disorders (Grisendi et al. 2005). Importantly, in acute promyelocytic leukemia, the fusion protein NPM/RAR $\alpha$ localizes in the nucleolus indicating a role of this nucleolar protein in this disease (Rego et al. 2006).

\section{Nucleolus and virus}

Within the last few years, increasing evidence has revealed that viruses require the nucleus and in particular the nucleolus to target proteins indispensable for their replication. An increasing number of key proteins from both DNA- and RNA-containing viruses are localized in the nucleolus: viruses of the family Herpesviridae, Adenoviridae, Hepadnaviridae, Retroviridae, Rhabdoviridae, Orthomyxoviridae, Potyviridae, Coronaviridae and Flaviviridae, encode such proteins. Viruses have developed different strategies to facilitate targeting of their proteins to the nucleolus: (1) it was reported that the sequences of certain viral proteins harbor NoLS and NES (Harris and Hope 2000; Hiscox 2007; Kann et al. 2007). Recently (Reed et al. 2006) it was demonstrated by mutagenesis that the nucleocapsid $(\mathrm{N})$ protein of infectious bronchitis virus (IBV), presents an 8 amino acid-long motif that functions as NoLS, and is necessary and sufficient for nucleolar retention of the $\mathrm{N}$ protein and colocalization with nucleolin and fibrillarin; the NoLS is required for interaction with cell factors. (2) Other viral proteins present sequences rich in arginine-lysine (Ghorbel et al. 2006; Reed et al. 2006) known to be nucleolar retention signals; generally, these sequences overlap the NLS. (3) Some viral proteins that target the nucleolus present motifs with affinity for double-stranded RNA (dsRNA), for RNA binding or for DNA binding (Melen et al. 2007). (4) Other studies showed that nucleolar localization of viral proteins, is cell cycle-dependent (Cawood et al. 2007); using synchronization studies coupled to live cell confocal microscopy, the authors demonstrated that the concentration of $\mathrm{N}$ protein in the nucleolus was higher in the $\mathrm{G} 2 / \mathrm{M}$ phase than in other phases, and that in this phase the protein was more mobile in the nucleoplasm. In all the cases examined, the viral proteins depend on cell factors to successfully shuttle between the nucleolus and the cytoplasm.

Why must viral proteins target to the nucleolus?

The answer to this question is not clear; however, different authors had reported that such viral proteins are involved both in replication of the viral genome, and in transcriptional and post-transcriptional regulation of viral genome expression (Dang and Lee 1989; Pyper et al. 1998). For example, some plants viruses are known to encode a protein designated movement protein, responsible for long-distance movement of the viral RNA through the phloem (Ryabov et al. 1999). Movement strictly depends on the interaction of the viral movement protein with the nucleolus and the Cajal bodies, which contain snRNPs and snoRNPs (Kim et al. 2007a, b). The open reading frame (ORF) 3 of Groundnut rosette virus is one such protein; it is first localized in Cajal bodies and forms Cajal body-like struc- 
tures, it is then localized in the nucleolus when the Cajal body-like structures fuse with the nucleolus, and finally it exits to the cytoplasm (Kim et al. 2007b). Another study showed that this shuttling is indispensable to form the RNPs essential for systemic virus infection (Kim et al. 2007a). In this process, the interaction of the viral ORF3 with fibrillarin is absolutely required. Interestingly, silencing of the fibrillarin gene blocks long-distance movement of the virus but does not affect virus replication and movement via plasmodesmata. Because the mobility of nucleolar components depends on the interactions and functions of the components (Olson and Dundr 2005), we suggest that targeting of viral proteins to the nucleolus could help viral protein traffic and diffusion of viral infection.

The activity of the human immunodeficiency virus (HIV)-1 Rev protein is essential for virus replication. Its subcellular localization is nucleolar, but it has the ability to shuttle continuously between the nucleus and the cytoplasm (Felber et al. 1989; Kalland et al. 1994). Rev possesses both an NES and an NLS; the NLS is associated with importin- $\beta$ as well as with B23 (Fankhauser et al. 1991; Henderson and Percipalle 1997). Rev-GFP movement in the nucleolus is very slow, implying that it is attached to affinity binding sites in this subcellular compartment (Daelemans et al. 2004). In addition, the transport of Rev from the nucleolus to the cytoplasm can be affected negatively by NF90, a cellular protein that colocalizes with Rev in the nucleolus (Urcuqui-Inchima et al. 2006) (Fig. 4). This indicates that the transport of HIV transcripts by Rev to the cytoplasm is a regulated process. Because Rev is concentrated in the nucleolus, it was suggested that the passage of Rev to the nucleolus is an indispensable step for Rev function, and hence for HIV-1 replication. Indeed, based on HIV-1 RNA trafficking through the nucleolus, this organelle is an essential participant of HIV-1 RNA export (Michienzi et al. 2000).

As discussed above for Rev, it has been shown that the Herpes virus saimiri ORF57 protein is required for nuclear export of viral intronless mRNAs (Boyne and Whitehouse 2006). In addition, the expression of ORF57 induces nuclear trafficking, which is essential for nuclear export of such RNAs; the human transcription/export protein involved in mRNA export, is redistributed to the nucleolus in the presence of the ORF57 protein. Based on these findings, the authors concluded that the nucleolus is required for nuclear export of the viral mRNAs.

What are the consequences for the cells of the passage of viral proteins via the nucleolus?

It is known that all viruses whether with DNA or RNA genomes interfere with the cell cycle, affecting host-cell functions and increasing the efficiency of virus replication.
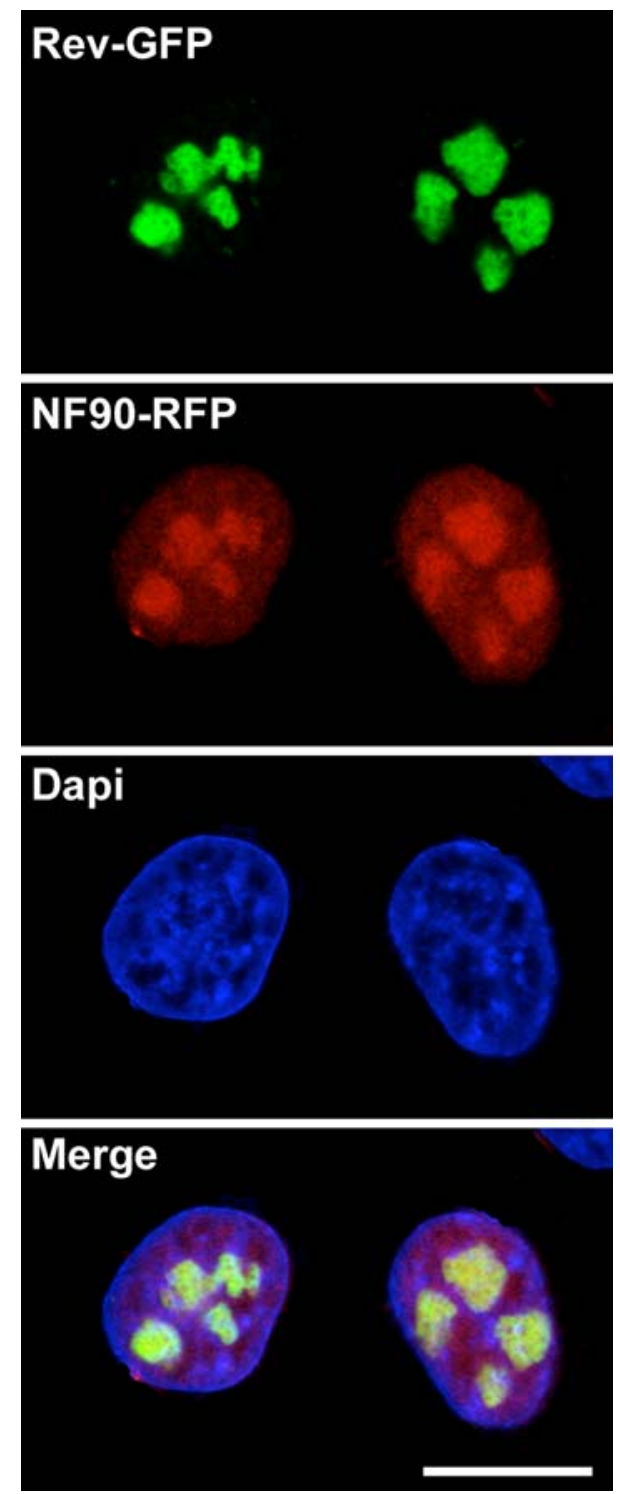

Fig. 4 HIV Rev-GFP and NF90-RFP fusions were expressed in HeLa cells. Both proteins colocalize in nucleoli as seen by the merge. The nucleus is visualized by Dapi staining. Bars: $10 \mu \mathrm{m}$

The data obtained suggest that targeting of virus proteins to the nucleolus not only facilitates virus replication, but may also be required for pathogenic processes. Recent studies following infection by IBV, revealed a change in the morphology and protein content of the nucleolus (Dove et al. 2006). This included an enlarged FC and an increase in protein content; interestingly, the tumor suppressor protein $\mathrm{p} 53$, normally localized in the nucleus in virus infected cells, was redistributed mainly in the cytoplasm. The Hepatitis B virus ( $\mathrm{HBV})$ core antigen $(\mathrm{HBcAg})$ is responsible for export of the virus with a mature genome (Yuan et al. 1999a, b). Indeed a change from isoleucine to leucine in position 97 (I97L) of $\mathrm{HBcAg}$ causes the cell to release virus particles with immature genomes. $\mathrm{HBcAg}$ with a mutation 
in position 97 (I97E or I97W) has been detected in the nucleolus colocalizing with nucleolin and B23, and this colocalization was often related with binucleated cells or apoptosis (Ning and Shih 2004), suggesting that the localization of $\mathrm{HBcAg}$ in the nucleolus could perturb cytokinesis. The authors propose that this event may be associated with liver pathogenesis.

Some factors expressed by west nile virus (WNV) such as NS2B and NS3 and the WNV capsid (WNVCp) participate in WNV-mediated apoptosis (Oh et al. 2006; Ramanathan et al. 2006). It is well known that p53 is activated in response to oncogenic or DNA damaging stresses, inducing cell cycle arrest and apoptosis (Harris and Levine 2005). In normal conditions, HDM2 targets p53 and blocks abnormal accumulation of $\mathrm{p} 53$ by HDM2-mediated ubiquitinylation, followed by $26 \mathrm{~S}$ proteasome-dependent degradation of p53 (Haupt et al. 1997; Kubbutat et al. 1997). Recently it was demonstrated that WNVCp could bind to and sequester HDM2 in the nucleolus, blocking p53-HDM2 complex formation (Yang et al. 2007). This phenomenon causes stabilization of p53 and Bax activation and thereafter apoptosis. In addition, the authors show that WNVCp is able to induce apoptosis-dependent processes, suggesting that the viral protein mediates apoptosis through p53-dependent mechanisms by retention of HDM2 in the nucleolus.

\section{Remarks and perspectives}

The conclusions are based on the perspectives and the tendency that can be anticipated from the present research in the field of the nucleolus.

We propose that in the future, a better understanding of the complexity and variability of ribosome biogenesis will need to be established. For example, the difference between the information available in yeast and mammalian cells is of major importance. The different steps of ribosome biogenesis and protein complexes are well characterized in yeast due to easy access of mutants. Similarly, Miller chromatin spreading for electron microscopy in yeast strains carrying mutations reveals the coupling of RNA pol I transcription with rRNA processing (Schneider et al. 2007). Additionally, the compaction into SSU processomes of pre$18 \mathrm{~S}$ ribosomal RNA before cleavage was observed on Miller spreads (Osheim et al. 2004). There is presently no comparable information for the mammalian genes. Yet the tendency is to generalize and suppose that the information is similar in the two models. In the future, differences will most probably be revealed as well as the complexity of the regulation in differentiated cells. Along this line, it was demonstrated that basonuclin, a cell-type-specific rDNA regulator transcribes only one subset of rDNAs of a cell (Zhang et al. 2007b). In such a differentiated cell, it remains to be established how the subset of rDNA repeats is selected.

The nucleolus was proposed to be a domain of the sequestration of molecules that normally operate outside this organelle, mainly in the nucleoplasm. Sequestration in the yeast nucleolus of the phosphatase cdc14 and its release into the cytoplasm at anaphase was demonstrated to be a key event in cell cycle progression (for a review see Cockell and Gasser 1999; Guarente 2000; Visintin and Amon 2000). However, it is important to recall that there is no nucleolus during mitosis in mammalian cells. In mammalian interphase cells, the nucleolus is a domain of retention of molecules related to cell cycle, life span, and apoptosis, and is in particular an actor of the p53-dependent pathway. Recently nucleolar retention of the Hand 1 transcription factor was observed in trophoblast stem cells (Martindill et al. 2007). Phosphorylation of Hand1 induced nucleolar to nucleoplasm translocation of Hand1 and commitment of stem cells to differentiate into giant cells. Hand1 translocation to the nucleoplasm might regulate a crucial step of stem cell differentiation into polyploid giant cells but the targets of Hand1 in the nucleoplasm are still undefined.

The nucleolus is generally surrounded by highly condensed chromatin first described in rat hepatocytes and presently known as heterochromatin. By following the movements of chromosome sequences introduced in different sites in chromosomes of living cells, it was demonstrated that loci at nucleoli periphery and nuclear periphery are less mobile than in other sites. Disruption of the nucleoli by a CK2 inhibitor increases the mobility of the perinucleolar loci. It was proposed that the nucleolus and nuclear periphery could maintain the three-dimensional organization of chromatin in the nucleus (Chubb et al. 2002). Recently the perinucleolar ring of chromatin was brought to the fore when its role in the maintenance of inactive $\mathrm{X}$ (Xi) was demonstrated (Zhang et al. 2007a). During middle and late $\mathrm{S}$ phase, $\mathrm{Xi}$ contacts the nucleolar periphery when it is replicated during the cell cycle. It was discovered that the perinucleolar chromatin is enriched in $\mathrm{Snf} 2 \mathrm{~h}$, the catalytic subunit of a remodeling complex required for replication of heterochromatin. These observations demonstrate the role of the perinucleolar compartment in maintaining the epigenetic state of Xi (Zhang et al. 2007a). The presence of inactive rDNA repeats in perinucleolar heterochromatin is known in many plant cells and in Drosophila. It was recently demonstrated that disruption in Drosophila of histone $\mathrm{H} 3 \mathrm{~K} 9$ methylation, a marker of heterochromatin, induced nucleolar disorganization and decondensation, and disorganization of rDNA repeats (Peng and Karpen 2007). The authors suggest that condensation of a part of the rDNA copies into heterochromatin could be a general strategy against recombination of these highly repeated genes. 
For long, interest concerning the nucleolus was to establish how efficient ribosome biogenesis occurs and the link of this function with the cell cycle. More recently the effect of the disruption of ribosome biogenesis appeared very important when it was proposed that the nucleolus is a sensor of stress (Rubbi and Milner 2003). Indeed disruption of ribosome biogenesis releases ribosomal proteins from the nucleolus that bind to MDM2 and inhibit p53 degradation (Lindstrom et al. 2007). A connection between ribosomal stress and p53-dependent cell cycle arrest is now proposed (Gilkes et al. 2006).

Considering the diversity of the recent information gathered on the nucleolus, it is clear that this is a very dynamic and rapidly progressing research area. The most promising aspect is the contribution of new models (pseudo-NORs, Prieto and McStay 2007), new species (not only yeast), new approaches (Miller spreads using mutants, proteomics) and new questions (for instance the role of siRNAs or antisens RNAs in the activity of the nucleolus).

Acknowledgments The authors thank J. Gébrane-Younès, T. Lechertier and M. J. Pébusque for the gift of images and A. L. Haenni for critical reading of the manuscript. This work was supported in part by grants from the Centre National de la Recherche Scientifique, the association pour la Recherche sur le Cancer (Contrat 3303) and Colciencias (Project 1115-34-319145). S. U-I is a recipient of a grant from the Centre National de la Recherche Scientifique.

\section{References}

Andersen JS, Lyon CE, Fox AH, Leung AKL, Lam YW, Steen H, Mann M, Lamond AI (2002) Directed proteomic analysis of the human nucleolus. Curr Biol 12:1-11

Andersen JS, Lam YW, Leung AK, Ong SE, Lyon CE, Lamond AI, Mann M (2005) Nucleolar proteome dynamics. Nature 433:77-83

Angelier N, Tramier M, Louvet E, Coppey-Moisan M, Savino TM, De Mey JR, Hernandez-Verdun D (2005) Tracking the interactions of rRNA processing proteins during nucleolar assembly in living cells. Mol Biol Cell 16:2862-2871

Arabi A, Wu S, Ridderstrale K, Bierhoff H, Shiue C, Fatyol K, Fahlen S, Hydbring P, Soderberg O, Grummt I et al (2005) c-Myc associates with ribosomal DNA and activates RNA polymerase I transcription. Nat Cell Biol 7:303-310

Azum-Gélade M-C, Noaillac-Depeyre J, Caizergues-Ferrer M, Gas N (1994) Cell cycle redistribution of U3 snRNA and fibrillarin. Presence in the cytoplasmic nucleolus remnant and in the prenucleolar bodies at telophase. J Cell Sci 107:463-475

Bachvarov D, Moss T (1991) The RNA polymerase I transcription factor xUBF contains 5 tandemly repeated HMG homology boxes. Nucleic Acids Res 19:2331-2335

Bartsch I, Schoneberg C, Grummt I (1988) Purification and characterization of TTFI, a factor that mediates termination of mouse ribosomal DNA transcription. Mol Cell Biol 8:3891-3897

Biggiogera M, Fakan S, Kaufmann SH, Black A, Shaper JH, Busch H (1989) Simultaneous immunoelectron microscopic visualization of protein B23 and C23 distribution in the HeLa cell nucleolus. J Histochem Cytochem 37:1371-1374

Bodem J, Dobreva G, Hoffmann-Rohrer U, Iben S, Zentgraf H, Delius $\mathrm{H}$, Vingron M, Grummt I (2000) TIF-IA, the factor mediating growth-dependent control of ribosomal RNA synthesis, is the mammalian homolog of yeast Rrn3p. EMBO Rep 1:171-175

Boisvert FM, van Koningsbruggen S, Navascues J, Lamond AI (2007) The multifunctional nucleolus. Nat Rev Mol Cell Biol 8:574-585

Borer RA, Lehner CF, Eppenberger HM, Nigg EA (1989) Major nucleolar proteins shuttle between nucleus and cytoplasm. Cell $56: 379-390$

Boulon S, Verheggen C, Jady BE, Girard C, Pescia C, Paul C, Ospina JK, Kiss T, Matera AG, Bordonne R, Bertrand E (2004) PHAX and CRM1 are required sequentially to transport U3 snoRNA to nucleoli. Mol Cell 16:777-787

Boyne JR, Whitehouse A (2006) Nucleolar trafficking is essential for nuclear export of intronless herpesvirus mRNA. Proc Natl Acad Sci USA 103:15190-15195

Carmo-Fonseca M, Mendes-Soares L, Campos I (2000) To be or not to be in the nucleolus. Nat Cell Biol 2:107-112

Carneiro T, Carvalho C, Braga J, Rino J, Milligan L, Tollervey D, Carmo-Fonseca M (2007) Depletion of the yeast nuclear exosome subunit Rrp6 results in accumulation of polyadenylated RNAs in a discrete domain within the nucleolus. Mol Cell Biol 27:4157-4165

Casafont I, Bengoechea R, Navascues J, Pena E, Berciano MT, Lafarga M (2007) The giant fibrillar center: a nucleolar structure enriched in upstream binding factor (UBF) that appears in transcriptionally more active sensory ganglia neurons. J Struct Biol 159:451-461

Caspersson TO (1950) Cell growth and cell function: W. W. Norton and Co., New York

Cavanaugh AH, Hirschler-Laszkiewicz I, Hu Q, Dundr M, Smink T, Misteli T, Rothblum LI (2002) Rrn3 phosphorylation is a regulatory checkpoint for ribosome biogenesis. J Biol Chem 277:27423-27432

Cawood R, Harrison SM, Dove BK, Reed ML, Hiscox JA (2007) Cell cycle dependent nucleolar localization of the coronavirus nucleocapsid protein. Cell Cycle 6:863-867

Chan PK, Qi Y, Amley J, Koller CA (1996) Quantitation of the nucleophosmin/B23-translocation using imaging analysis. Cancer Lett 100:191-197

Chen D, Huang S (2001) Nucleolar components involved in ribosome biogenesis cycle between the nucleolus and nucleoplasm in interphase cells. J Cell Biol 153:169-176

Chen D, Dundr M, Wang C, Leung A, Lamond A, Misteli T, Huang S (2005) Condensed mitotic chromatin is accessible to transcription factors and chromatin structural proteins. J Cell Biol 168:41-54

Chubb JR, Boyle S, Perry P, Bickmore WA (2002) Chromatin motion is constrained by association with nuclear compartments in human cells. Curr Biol 12:439-445

Clos J, Normann A, Ohrlein A, Grummt I (1986) The core promoter of mouse rDNA consists of two functionally distinct domains. Nucleic Acids Res 14:7581-7595

Clute P, Pines J (1999) Temporal and spatial control of cyclin B1 destruction in metaphase. Nature cell Biol 1:82-87

Cmarko D, Verschure PJ, Rothblum LI, Hernandez-Verdun D, Amalric F, van Driel R, Fakan S (2000) Ultrastructural analysis of nucleolar transcription in cells microinjected with 5-bromo-UTP. Histochem Cell Biol 113:181-187

Cockell MM, Gasser SM (1999) The nucleolus: nucleolar space for rent. Current Biology 9:R575-R576

Colau G, Thiry M, Leduc V, Bordonne R, Lafontaine DL (2004) The small nucle(ol)ar RNA cap trimethyltransferase is required for ribosome synthesis and intact nucleolar morphology. Mol Cell Biol 24:7976-7986

Comai L, Zomerdijk JC, Beckmann H, Zhou S, Admon A, Tjian R (1994) Reconstitution of transcription factor SL1: exclusive binding of TBP by SL1 or TFIID subunits. Science 266:1966-1972

D'Amours D, Stegmeier F, Amon A (2004) Cdc14 and condensin control the dissolution of cohesin-independent chromosome linkages at repeated DNA. Cell 117:455-469 
Daelemans D, Costes SV, Cho EH, Erwin-Cohen RA, Lockett S, Pavlakis GN (2004) In vivo HIV-1 Rev multimerization in the nucleolus and cytoplasm identified by fluorescence resonance energy transfer. J Biol Chem 279:50167-50175

Dang CV, Lee WMF (1989) Nuclear and nucleolar targeting sequences of c-erb-A, c-myb, N-myc, p53, HSP70, and HIV tat proteins. J Biol Chem 264:18019-18023

David-Pfeuty T, Nouvian-Dooghe Y, Sirri V, Roussel P, HernandezVerdun D (2001) Common and reversible regulation of wild-type p53 function and of ribosomal biogenesis by protein kinases in human cells. Oncogene 20:5951-5963

de la Cruz J, Kressler D, Linder P (2004) Ribosome subunit assembly. In: Olson MOJ (eds) The nucleolus. Landes Biosciences/eurekah.com, Austin, pp 258-285

Dez C, Houseley J, Tollervey D (2006) Surveillance of nuclear-restricted pre-ribosomes within a subnucleolar region of Saccharomyces cerevisiae. EMBO J 25:1534-1546

Dousset T, Wang C, Verheggen C, Chen D, Hernandez-Verdun D, Huang S (2000) Initiation of nucleolar assembly is independent of RNA polmerase I transcription. Mol Biol Cell 11:2705-2717

Dove BK, You JH, Reed ML, Emmett SR, Brooks G, Hiscox JA (2006) Changes in nucleolar morphology and proteins during infection with the coronavirus infectious bronchitis virus. Cell Microbiol 8:1147-1157

Dragon F, Gallagher JE, Compagnone-Post PA, Mitchell BM, Porwancher KA, Wehner KA, Wormsley S, Settlage RE, Shabanowitz J, Osheim Y et al (2002) A large nucleolar U3 ribonucleoprotein required for 18S ribosomal RNA biogenesis. Nature 417:967-970

Dundr M, Misteli T, Olson MOJ (2000) The dynamics of postmitotic reassembly of the nucleolus. J Cell Biol 150:433-446

Dundr M, Hebert MD, Karpova TS, Stanek D, Xu H, Shpargel KB, Meier UT, Neugebauer KM, Matera AG, Misteli T (2004) In vivo kinetics of Cajal body components. J Cell Biol 164:831-842

Emiliani V, Sanvitto D, Tramier M, Piolot T, Petrasek Z, Kemnitz K, Durieux C, Coppey-Moisan M (2003) Low-intensity two-dimensional imaging of fluorescence lifetimes in living cells. Appl Phys Lett 83:2471-2473

Fan H, Penman S (1971) Regulation of synthesis and processing of nucleolar components in metaphase-arrested cells. J Mol Biol 59:27-42

Fankhauser C, Izaurralde E, Adachi Y, Wingfield P, Laemmli UK (1991) Specific complex of human immunodeficiency virus type $1 \mathrm{rev}$ and nucleolar B23 proteins: dissociation by the Rev response element. Mol Cell Biol 11:2567-2575

Fatica A, Tollervey D (2002) Making ribosomes. Curr Opin Cell Biol $14: 313-318$

Felber BK, Hadzopoulou-Cladaras M, Cladaras C, Copeland T, Pavlakis GN (1989) rev protein of human immunodeficiency virus type 1 affects the stability and transport of the viral mRNA. Proc Natl Acad Sci USA 86:1495-1499

Fomproix N, Gébrane-Younès J, Hernandez-Verdun D (1998) Effects of anti-fibrillarin antibodies on building of functional nucleoli at the end of mitosis. J Cell Sci 111: 359-372

Ford E, Voit R, Liszt G, Magin C, Grummt I, Guarente L (2006) Mammalian Sir2 homolog SIRT7 is an activator of RNA polymerase I transcription. Genes Dev 20:1075-1080

Fromont-Racine M, Senger B, Saveanu C, Fasiolo F (2003) Ribosome assembly in eukaryotes. Gene 313:17-42

Gautier T, Robert-Nicoud M, Guilly M-N, Hernandez-Verdun D (1992) Relocation of nucleolar proteins around chromosomes at mitosis-a study by confocal laser scanning microscopy. J Cell Sci 102:729-737

Gautier T, Fomproix N, Masson C, Azum-Gélade MC, Gas N, Hernandez-Verdun D (1994) Fate of specific nucleolar perichromosomal proteins during mitosis: cellular distribution and association with U3 snoRNA. Biol Cell 82:81-93
Gébrane-Younès J, Sirri V, Junéra HR, Roussel P, Hernandez-Verdun D (2005) Nucleolus: an essential nuclear domain In: Hemmerich P, Diekmann S (eds) Visions of the cell nucleus. ASP, CA pp 120-135

Gerbi SA, Borovjagin AV (2004) Pre-Ribosomal RNA processing in multicellular organisms In: Olson MOJ (eds) The nucleolus. Landes Biosciences/eurekah.com, Austin, pp 170-198

Ghorbel S, Sinha-Datta U, Dundr M, Brown M, Franchini G, Nicot C (2006) Human T-cell leukemia virus type I p30 nuclear/nucleolar retention is mediated through interactions with RNA and a constituent of the 60 S ribosomal subunit. J Biol Chem 281:37150 37158

Gilkes DM, Chen L, Chen J (2006) MDMX regulation of p53 response to ribosomal stress. EMBO J 25:5614-5625

Gill G (2004) SUMO and ubiquitin in the nucleus: different functions, similar mechanisms? Genes Dev 18:2046-2059

Ginisty H, Amalric F, Bouvet P (1998) Nucleolin functions in the first step of ribosomal RNA processing. EMBO J 17:1476-1486

Goessens G, Thiry M, Lepoint A (1987) Relations between nucleoli and nucleolus-organizing regions during the cell cycle. Chromosome Today 9:261-271

Gong L, Yeh ET (2006) Characterization of a family of nucleolar SUMO-specific proteases with preference for SUMO-2 or SUMO-3. J Biol Chem 281:15869-15877

Gorski JJ, Pathak S, Panov K, Kasciukovic T, Panova T, Russell J, Zomerdijk JC (2007) A novel TBP-associated factor of SL1 functions in RNA polymerase I transcription. EMBO J 26:1560-1568

Grandi P, Rybin V, Bassler J, Petfalski E, Strauss D, Marzioch M, Schafer T, Kuster B, Tschochner H, Tollervey D et al (2002) 90S pre-ribosomes include the $35 \mathrm{~S}$ pre-rRNA, the U3 snoRNP, and $40 \mathrm{~S}$ subunit processing factors but predominantly lack 60S synthesis factors. Mol Cell 10:105-115

Grandori C, Gomez-Roman N, Felton-Edkins ZA, Ngouenet C, Galloway DA, Eisenman RN, White RJ (2005) c-Myc binds to human ribosomal DNA and stimulates transcription of rRNA genes by RNA polymerase I. Nat Cell Biol 7:311-318

Grisendi S, Bernardi R, Rossi M, Cheng K, Khandker L, Manova K, Pandolfi PP (2005) Role of nucleophosmin in embryonic development and tumorigenesis. Nature 437:147-153

Guarente L (2000) Sir2 links chromatin silencing, metabolism, and aging. Genes Dev 14:1021-1026

Guillot PV, Martin S, Pombo A (2005) The organization of transcription in the nucleus of mammalian cells. In: Hemmerich P, Diekmann S (eds) Visions of the cell nucleus. ASP, CA, pp 95-105

Hadjiolov AA (1985) The nucleolus and ribosome biogenesis. In: Alfert M, Beermann W, Goldstein L, Porter KR, Sitte P (eds) Cell biology monographs. Springer, Wien, p 12

Hadjiolova KV, Hadjiolov A, Bachelerie J-P (1995) Actinomycin D stimulates the transcription of rRNA minigenes transfected into mouse cells. Applications for the in vivo hypersensitivity of rRNA gene transcription. Eur J Biochem 228:605-615

Haltiner MM, Smale ST, Tjian R (1986) Two distinct promoter elements in the human rRNA gene identified by linker scanning mutagenesis. Mol Cell Biol 6:227-235

Harris ME, Hope TJ (2000) RNA export: insights from viral models. Essays Biochem 36:115-127

Harris SL, Levine AJ (2005) The p53 pathway: positive and negative feedback loops. Oncogene 24:2899-2908

Haupt Y, Maya R, Kazaz A, Oren M (1997) Mdm2 promotes the rapid degradation of p53. Nature 387:296-299

Heix J, Vente A, Voit R, Budde A, Michaelidis TM, Grummt I (1998) Mitotic silencing of human rRNA synthesis: inactivation of the promoter selectivity factor SL1 by cdc2/cyclin B-mediated phosphorylation. EMBO J 17:7373-7381

Henderson BR, Percipalle P (1997) Interactions between HIV Rev and nuclear import and export factors: the Rev nuclear localisation 
signal mediates specific binding to human importin-beta. J Mol Biol 274:693-707

Hernandez-Verdun D, Junéra HR (1995) The nucleolus In: Principles of medical biology, cellular organels, vol 2. Jai Press Inc., USA, pp 73-92

Hernandez-Verdun D (2006) The nucleolus: a model for the organization of nuclear functions. Histochem Cell Biol 126:135-148

Hernandez-Verdun D, Roussel P, Gautier T (1993) Nucleolar proteins during mitosis. Chromosomes Today 11:79-90

Hiscox JA (2007) RNA viruses: hijacking the dynamic nucleolus. Nat Rev Microbiol 5:119-127

Hozak P, Novak JT, Smetana K (1989) Three-dimensional reconstructions of nucleolus-organizing regions in PHA-stimulated human lymphocytes. Biol Cell 66:225-233

Hozàk P, Cook PR, Schöfer C, Mosgöller W, Wachtler F (1994) Site of transcription of ribosomal RNA and intranucleolar structure in HeLa cells. J Cell Sci 107:639-648

Jansa P, Grummt I (1999) Mechanism of transcription termination: PTRF interacts with the largest subunit of RNA polymerase I and dissociates paused transcription complexes from yeast and mouse. Mol Gen Genet 262:508-514

Jantzen HM, Admon A, Bell SP, Tjian R (1990) Nucleolar transcription factor hUBF contains a DNA-binding motif with homology to HMG proteins. Nature 344:830-836

Jiménez-Garcia LF, Segura-Valdez MdL, Ochs RL, Rothblum LI, Hannan R, Spector DL (1994) Nucleologenesis: U3 snRNA-containing prenucleolar bodies move to sites of active Pre-rRNA transcription after mitosis. Mol Biol Cell 5:955-966

Kalland KH, Szilvay AM, Brokstad KA, Saetrevik W, Haukenes G (1994) The human immunodeficiency virus type $1 \mathrm{Rev}$ protein shuttles between the cytoplasm and nuclear compartments. Mol Cell Biol 14:7436-7444

Kann M, Schmitz A, Rabe B (2007) Intracellular transport of hepatitis B virus. World J Gastroenterol 13:39-47

Kim SH, Macfarlane S, Kalinina NO, Rakitina DV, Ryabov EV, Gillespie T, Haupt S, Brown JW, Taliansky M (2007a) Interaction of a plant virus-encoded protein with the major nucleolar protein fibrillarin is required for systemic virus infection. Proc Natl Acad Sci USA 104:11115-11120

Kim SH, Ryabov EV, Kalinina NO, Rakitina DV, Gillespie T, MacFarlane S, Haupt S, Brown JW, Taliansky M (2007b) Cajal bodies and the nucleolus are required for a plant virus systemic infection. EMBO J 26:2169-2179

Knibiehler B, Mirre C, Rosset R (1982) Nucleolar organizer structure and activity in a nucleolus without fibrillar centres:the nucleolus in an established Drosophila cell line. J Cell Sci 57:351-364

Knibiehler B, Mirre C, Navarro A, Rosset R (1984) Studies on chromatin organization in a nucleolus without fibrillar centres. Presence of sub-nucleolar structure in KCo cells of Drosophila. Cell Tissue Res 236:279-288

Korgaonkar C, Hagen J, Tompkins V, Frazier AA, Allamargot C, Quelle FW, Quelle DE (2005) Nucleophosmin (B23) targets ARF to nucleoli and inhibits its function. Mol Cell Biol 25:1258-1271

Kubbutat MH, Jones SN, Vousden KH (1997) Regulation of p53 stability by Mdm2. Nature 387:299-303

Kubota S, Siomi H, Satoh T, Endo S, Maki M, Hatanaka M (1989) Functional similarity of HIV-I rev and HTLV-I rex proteins: identification of a new nucleolar-targeting signal in rev protein. Biochem Biophys Res Commun 162:963-970

LaCava J, Houseley J, Saveanu C, Petfalski E, Thompson E, Jacquier A, Tollervey D (2005) RNA degradation by the exosome is promoted by a nuclear polyadenylation complex. Cell 121:713-724

Lafarga M, Berciano MT, Hervas JP, Villegas J (1989) Nucleolar organization in granule cell neurons of the rat cerebellum. J Neurocytol 18:19-26
Längst G, Blank TA, Becker PB, Grummt I (1997) RNA polymerase I transcription on nucleosomal templates: the transcription termination factor TTF-1 induces chromatin remodeling and relieves transcriptional repression. EMBO J 16:760-768

Learned RM, Cordes S, Tjian R (1985) Purification and characterization of a transcription factor that confers promoter specificity to human RNA polymerase I. Mol Cell Biol 5:1358-1369

Lechertier T, Sirri V, Hernandez-Verdun D, Roussel P (2007) A B23interacting sequence as a tool to visualize protein interactions in a cellular context. J Cell Sci 120:265-275

Leung AK, Andersen JS, Mann M, Lamond AI (2003) Bioinformatic analysis of the nucleolus. Biochem J 376:553-569

Leung AK, Gerlich D, Miller G, Lyon C, Lam YW, Lleres D, Daigle N, Zomerdijk J, Ellenberg J, Lamond AI (2004) Quantitative kinetic analysis of nucleolar breakdown and reassembly during mitosis in live human cells. J Cell Biol 166:787-800

Li YP (1997) Protein B23 is an important human factor for the nucleolar localization of the human immunodeficiency virus protein Tat. J Virol 71:4098-4102

Li J, Langst G, Grummt I (2006) NoRC-dependent nucleosome positioning silences rRNA genes. EMBO J 25:5735-5741

Liau MC, Perry RP (1969) Ribosome precursor particles in nucleoli. J Cell Biol 42:272-283

Lindstrom MS, Jin A, Deisenroth C, White Wolf G, Zhang Y (2007) Cancer-associated mutations in the MDM2 zinc finger domain disrupt ribosomal protein interaction and attenuate MDM2-induced p53 degradation. Mol Cell Biol 27:1056-1068

Lippincott-Schwartz J, Snapp E, Kenworthy A (2001) Studying protein dynamics in living cells. Nat Rev Mol Cell Biol 2:444-456

Louvet E, Junera HR, Le Panse S, Hernandez-Verdun D (2005) Dynamics and compartmentation of the nucleolar processing machinery. Exp Cell Res 304:457-470

Louvet E, Junera HR, Berthuy I, Hernandez-Verdun D (2006) Compartmentation of the Nucleolar Processing Proteins in the Granular Component is a CK2-driven Process. Mol Biol Cell 17:25372546

Mais C, Wright JE, Prieto JL, Raggett SL, McStay B (2005) UBFbinding site arrays form pseudo-NORs and sequester the RNA polymerase I transcription machinery. Genes Dev 19:50-64

Mariano AR, Colombo E, Luzi L, Martinelli P, Volorio S, Bernard L, Meani N, Bergomas R, Alcalay M, Pelicci PG (2006) Cytoplasmic localization of NPM in myeloid leukemias is dictated by gain-of-function mutations that create a functional nuclear export signal. Oncogene 25:4376-4380

Martindill DM, Risebro CA, Smart N, Franco-Viseras Mdel M, Rosario CO, Swallow CJ, Dennis JW, Riley PR (2007) Nucleolar release of Hand1 acts as a molecular switch to determine cell fate. Nat Cell Biol 9:1131-1141

McClintock B (1934) The relation of a particular chromosomal element to the development of the nucleoli in Zea mays. Z Zellforsch Mikrosk Anat 21:294-328

Meggio F, Pinna LA (2003) One-thousand-and-one substrates of protein kinase CK2? FASEB J 17:349-368

Melen K, Kinnunen L, Fagerlund R, Ikonen N, Twu KY, Krug RM, Julkunen I (2007) Nuclear and nucleolar targeting of influenza A virus NS1 protein: striking differences between different virus subtypes. J Virol 81:5995-6006

Mélèse T, Xue Z (1995) The nucleolus : an organelle formed by the act of building a ribosome. Curr Opin Cell Biol 7:319-324

Michienzi A, Cagnon L, Bahner I, Rossi JJ (2000) Ribozyme-mediated inhibition of HIV 1 suggests nucleolar trafficking of HIV-1 RNA. Proc Natl Acad Sci USA 97:8955-8960

Miller G, Panov KI, Friedrich JK, Trinkle-Mulcahy L, Lamond AI, Zomerdijk JCBM (2001) hRRN3 is essential in the SL1-mediated recruitment of RNA polymerase I to rRNA gene promoters. EMBO J 20:1373-1382 
Misteli T (2001) Protein dynamics: implications for nuclear architecture and gene expression. Science 291:843-847

Montgomery TH (1898) Comparative cytological studies, with especial regard to the morphology of the nucleolus. J Morphol $15: 265-582$

Moorefield B, Greene EA, Reeder RH (2000) RNA polymerase I transcription factor Rrn3 is functionally conserved between yeast and human. Proc Natl Acad Sci USA 97:4724-4729

Muth V, Nadaud S, Grummt I, Voit R (2001) Acetylation of TAF(I)68, a subunit of TIF-IB/SL1, activates RNA polymerase I transcription. EMBO J 20:1353-1362

Negi SS, Olson MO (2006) Effects of interphase and mitotic phosphorylation on the mobility and location of nucleolar protein B23. J Cell Sci 119:3676-3685

Ning B, Shih C (2004) Nucleolar localization of human hepatitis B virus capsid protein. J Virol 78:13653-13668

Nishida T, Tanaka H, Yasuda H (2000) A novel mammalian Smt3-specific isopeptidase 1 (SMT3IP1) localized in the nucleolus at interphase. Eur J Biochem 267:6423-6427

Ochs RL, Lischwe MA, Shen E, Caroll RE, Busch H (1985a) Nucleologenesis: composition and fate of prenucleolar bodies. Chromosoma 92:330-336

Ochs RL, Lischwe MA, Spohn WH, Busch H (1985b) Fibrillarin: a new protein of the nucleolus identified by autoimmune sera. Biol Cell 54:123-134

Oh W, Yang MR, Lee EW, Park KM, Pyo S, Yang JS, Lee HW, Song J (2006) Jab1 mediates cytoplasmic localization and degradation of West Nile virus capsid protein. J Biol Chem 281:30166-30174

Okuwaki M, Tsujimoto M, Nagata K (2002) The RNA binding activity of a ribosome biogenesis factor, nucleophosmin/B23, is modulated by phosphorylation with a cell cycle-dependent kinase and by association with its subtype. Mol Biol Cell 13:2016-2030

Olson MOJ (2004) Nontraditional roles of the nucleolus In: Olson MOJ (eds) The nucleolus. Landes Bioscience, Georgetown, pp 329-342

Olson MO, Dundr M (2005) The moving parts of the nucleolus. Histochem Cell Biol 123:203-216

Osheim YN, French SL, Keck KM, Champion EA, Spasov K, Dragon F, Baserga SJ, Beyer AL (2004) Pre-18S ribosomal RNA is structurally compacted into the SSU processome prior to being cleaved from nascent transcripts in Saccharomyces cerevisiae. Mol Cell 16:943-954

Patterson GH, Lippincott-Schwartz J (2002) A photoactivatable GFP for selective photolabeling of proteins and cells. Science 297:1873-1877

Pébusque MJ, Seïte (1981) Electron microscopic studies of silverstained proteins in nucleolar organizer regions: location in nucleoli of rat sympathetic neurons during light and dark periods. J Cell Sci 51:85-94

Pederson T (1998) The plurifunctional nucleolus. Nucleic Acids Res 26:3871-3876

Pelletier G, Stefanovsky VY, Faubladier M, Hirschler-Laszkiewicz I, Savard J, Rothblum LI, Cote J, Moss T (2000) Competitive recruitment of CBP and $\mathrm{Rb}-\mathrm{HDAC}$ regulates $\mathrm{UBF}$ acetylation and ribosomal transcription. Mol Cell 6:1059-1066

Peng JC, Karpen GH (2007) H3K9 methylation and RNA interference regulate nucleolar organization and repeated DNA stability. Nat Cell Biol 9:25-35

Perry RP (1962) The cellular sites of ribosomal and 4S RNA. Proc Natl Acad Sci USA 48:2179-2186

Pestov DG, Strezoska Z, Lau LF (2001) Evidence of p53-dependent cross-talk between ribosome biogenesis and cell cycle: effects of nucleolar protein Bop1 on G1/S transition. Mol Cell Biol 21:4246-4255

Peyroche G, Milkereit P, Bischler N, Tschochner H, Schultz P, Sentenac A, Carles C, Riva M (2000) The recruitment of RNA polymerase I on rDNA is mediated by the interaction of the A43 subunit with Rrn3. EMBO J 19:5473-5482

Phair RD, Misteli T (2000) High mobility of proteins in the mammalian cell nucleus. Nature 404:604-609

Pikaard CS, McStay B, Schultz MC, Bell SP, Reeder RH (1989) The Xenopus ribosomal gene enhancers bind an essential polymerase I transcription factor, xUBF. Genes Dev 3:1779-1788

Politz JC, Lewandowski LB, Pederson T (2002) Signal recognition particle RNA localization within the nucleolus differs from the classical sites of ribosome synthesis. J Cell Biol 159:411-418

Prieto JL, McStay B (2007) Recruitment of factors linking transcription and processing of pre-rRNA to NOR chromatin is UBFdependent and occurs independent of transcription in human cells. Genes Dev 21:2041-2054

Puvion-Dutilleul F, Bachellerie J-P, Puvion E (1991) Nucleolar organization of HeLa cells as studied by in situ hybridization. Chromosoma 100:395-409

Puvion-Dutilleul F, Puvion E, Bachellerie J-P (1997) Early stages of pre-rRNA formation within the nucleolar ultrastructure of mouse cells studied by in situ hybridization with 5'ETS leader probe. Chromosoma 105:496-505

Pyper JM, Clements JE, Zink MC (1998) The nucleolus is the site of Borna disease virus RNA transcription and replication. J Virol 72:7697-7702

Ramanathan MP, Chambers JA, Pankhong P, Chattergoon M, Attatippaholkun W, Dang K, Shah N, Weiner DB (2006) Host cell killing by the West Nile virus NS2B-NS3 proteolytic complex: NS3 alone is sufficient to recruit caspase-8-based apoptotic pathway. Virology 345:56-72

Raska I, Shaw PJ, Cmarko D (2006) New insights into nucleolar architecture and activity. Int Rev Cytol 255:177-235

Raué HA (2004) Pre-ribosomal RNA processing and assembly in Saccharomyces cerevisiae: the machine that makes the machine In: Olson MOJ (ed) The nucleolus. Landes Biosciences/eurekah. com, Austin, pp 199-222

Reed ML, Dove BK, Jackson RM, Collins R, Brooks G, Hiscox JA (2006) Delineation and modelling of a nucleolar retention signal in the coronavirus nucleocapsid protein. Traffic 7:833-848

Rego E, Ruggero D, Tribioli C, Gattoretti G, Kogan S, Redner R, Pandolfi PP (2006) Leukemia with distinct phenotypes in transgenic mice expressing PML/RARa, PLZF/RARa or NPM/RARa. Oncogene 25:1974-1979

Ritossa F, Spiegelman S (1965) Localization of DNA complementary to rRNA in the nucleolus organizer region of Drosophila melanogaster. Proc Natl Acad Sci USA 53:737-745

Roussel P, Hernandez-Verdun D (1994) Identification of Ag-NOR proteins, markers of proliferation related to ribosomal gene activity. Exp Cell Res 214:465-472

Roussel P, Belenguer P, Amalric F, Hernandez-Verdun D (1992) Nucleolin is an Ag-NOR protein; this property is determined by its amino-terminal domain independently of its phosphorylation state. Exp Cell Res 203:259-269

Roussel P, André C, Masson C, Géraud G, Hernandez-Verdun D (1993) Localization of the RNA polymerase I transcription factor hUBF during the cell cycle. J Cell Sci 104:1327-1337

Roussel P, André C, Comai L, Hernandez-Verdun D (1996) The rDNA transcription machinery is assembled during mitosis in active NORs and absent in inactive NORs. J Cell Biol 133:235-246

Rubbi CP, Milner J (2003) Disruption of the nucleolus mediates stabilization of p53 in response to DNA damage and other stresses. EMBO J 22:6068-6077

Ruggero D, Pandolfi PP (2003) Does the ribosome translate cancer? Nat Rev Cancer 3:179-192

Ryabov EV, Robinson DJ, Taliansky ME (1999) A plant virus-encoded protein facilitates long-distance movement of heterologous viral RNA. Proc Natl Acad Sci USA 96:1212-1217 
Santoro R, Li J, Grummt I (2002) The nucleolar remodeling complex NoRC mediates heterochromatin formation and silencing of ribosomal gene transcription. Nat Genet 32:393-396

Savino TM, Bastos R, Jansen E, Hernandez-Verdun D (1999) The nucleolar antigen Nop52, the human homologue of the yeast ribosomal RNA processing RRP1, is recruited at late stages of nucleologenesis. J Cell Sci 112:1889-1900

Savino TM, Gébrane-Younès J, De Mey J, Sibarita J-B, HernandezVerdun D (2001) Nucleolar assembly of the rRNA processing machinery in living cells. J Cell Biol 153:1097-1110

Scheer U, Benavente R (1990) Functional and dynamic aspects of the mammalian nucleolus. BioEssays 12:14-21

Scheer U, Hock R (1999) Structure and function of the nucleolus. Curr Opin Cell Biol 11:385-390

Scheer U, Weisenberger D (1994) The nucleolus. Curr Opin Cell Biol 6:354-359

Scheer U, Thiry M, Goessens G (1993) Structure, function and assembly of the nucleolus. Trends Cell Biol 3:236-241

Schnapp G, Schnapp A, Rosenbauer H, Grummt I (1994) TIF-IC, a factor involved in both transcription initiation and elongation of RNA polymerase I. Embo J 13:4028-4035

Schneider DA, Michel A, Sikes ML, Vu L, Dodd JA, Salgia S, Osheim YN, Beyer AL, Nomura M (2007) Transcription elongation by RNA polymerase I is linked to efficient rRNA processing and ribosome assembly. Mol Cell 26:217-229

Shav-Tal Y, Blechman J, Darzacq X, Montagna C, Dye BT, Patton JG, Singer RH, Zipori D (2005) Dynamic sorting of nuclear components into distinct nucleolar caps during transcriptional inhibition. Mol Biol Cell 16:2395-2413

Shaw PJ, Jordan EG (1995) The nucleolus. Annu Rev Cell Dev Biol 11:93-121

Siomi H, Shida H, Nam SH, Nosaka T, Maki M, Hatanaka M (1988) Sequence requirements for nucleolar localization of human $\mathrm{T}$ cell leukemia virus type I $\mathrm{pX}$ protein, which regulates viral RNA processing. Cell 55:197-209

Sirri V, Roussel P, Gendron MC, Hernandez-Verdun D (1997) Amount of the two major Ag-NOR proteins, nucleolin, and protein B23 is cell-cycle dependent. Cytometry $28: 147-156$

Sirri V, Roussel P, Hernandez-Verdun D (1999) The mitotically phosphorylated form of the transcription termination factor TTF- 1 is associated with the repressed rDNA transcription machinery. J Cell Sci 112:3259-3268

Sirri V, Roussel P, Hernandez-Verdun D (2000) In vivo release of mitotic silencing of ribosomal gene transcription does not give rise to precursor ribosomal RNA processing. J Cell Biol 148:259-270

Sirri V, Hernandez-Verdun D, Roussel P (2002) Cyclin-dependent kinases govern formation and maintenance of the nucleolus. J Cell Biol 156:969-981

Snaar S, Wiesmeijer K, Jochemsen AG, Tanke HJ, Dirks RW (2000) Mutational analysis of fibrillarin and its mobility in living human cells. J Cell Biol 151:653-662

Sollner-Webb B, Tycowski KT, Steitz JA (1996) Ribosomal RNA processing in eukaryotes In: Ribosomal RNA: structure, evolution, processing, and function in protein biosynthesis. CRC Press, New York, pp 469-490

Song Z, Wu M (2005) Identification of a novel nucleolar localization signal and a degradation signal in survivin-deltaEx3: a potential link between nucleolus and protein degradation. Oncogene 24:2723-2734

Sprague BL, McNally JG (2005) FRAP analysis of binding: proper and fitting. Trends Cell Biol 15:84-91

Stevens B (1965) The fine structure of the nucleolus during mitosis in the grasshopper neuroblast cell. J Cell Biol 24:349-368

Strohner R, Nemeth A, Jansa P, Hofmann-Rohrer U, Santoro R, Langst G, Grummt I (2001) NoRC-a novel member of mammalian
ISWI-containing chromatin remodeling machines. EMBO J 20:4892-4900

Strouboulis J, Wolffe AP (1996) Functional compartmentalization of the nucleus. J Cell Sci 109:1991-2000

Sullivan M, Higuchi T, Katis VL, Uhlmann F (2004) Cdc14 phosphatase induces rDNA condensation and resolves cohesin-independent cohesion during budding yeast anaphase. Cell 117:471-482

Thiry M, Goessens G (1996) The nucleolus during the cell cycle (MBI Unit, ed), Springer, Heidelberg

Thiry M, Lafontaine DL (2005) Birth of a nucleolus: the evolution of nucleolar compartments. Trends Cell Biol 15:194-199

Tollervey D (1996) Trans-acting factors in ribosome synthesis. Exp Cell Res 229:226-232

Torres-Rosell J, Machin F, Jarmuz A, Aragon L (2004) Nucleolar segregation lags behind the rest of the genome and requires Cdc14p activation by the FEAR network. Cell Cycle 3:496-502

Tsai RY, McKay RD (2002) A nucleolar mechanism controlling cell proliferation in stem cells and cancer cells. Genes and Dev 16:2991-3003

Tsai RY, McKay RD (2005) A multistep, GTP-driven mechanism controlling the dynamic cycling of nucleostemin. J Cell Biol 168:179-184

Urcuqui-Inchima S, Castano ME, Hernandez-Verdun D, St-Laurent G 3rd, Kumar A (2006) Nuclear factor 90, a cellular dsRNA binding protein inhibits the HIV Rev-export function. Retrovirology 3:83

Valdez BC, Perlaky L, Henning D, Saijo Y, Chan PK, Busch H (1994) Identification of the nuclear and nucleolar localization signals of the protein $\mathrm{p} 120$. Interaction with translocation protein B23. J Biol Chem 269:23776-23783

Verheggen C, Mouaikel J, Thiry M, Blanchard JM, Tollervey D, Bordonne R, Lafontaine DL, Bertrand E (2001) Box C/D small nucleolar RNA trafficking involves small nucleolar RNP proteins, nucleolar factors and a novel nuclear domain. EMBO J 20:5480-5490

Visintin R, Amon A (2000) The nucleolus: the magician's hat for cell cycle tricks. Curr Opin Cell Biol 12:372-377

Voit R, Schnapp A, Kuhn A, Rosenbauer H, Hirschmann P, Stunnenberg HG, Grummt I (1992) The nucleolar transcription factor mUBF is phosphorylated by casein kinase II in the C-terminal hyperacidic tail which is essential for transactivation. EMBO J 11:2211-2218

Voit R, Hoffmann M, Grummt I (1999) Phosphorylation by G1-specific cdk-cyclin complexes activates the nucleolar transcription factor UBF. EMBO J 18:1891-1899

Watkins NJ, Dickmanns A, Luhrmann R (2002) Conserved stem II of the box C/D motif is essential for nucleolar localization and is required, along with the $15.5 \mathrm{~K}$ protein, for the hierarchical assembly of the box C/D snoRNP. Mol Cell Biol 22:8342-8352

Watkins NJ, Lemm I, Ingelfinger D, Schneider C, Hossbach M, Urlaub H, Luhrmann R (2004) Assembly and maturation of the U3 snoRNP in the nucleoplasm in a large dynamic multiprotein complex. Mol Cell 16:789-798

Watkins NJ, Lemm I, Luhrmann R (2007) Involvement of nuclear import and export factors in U8 Box C/D snoRNP biogenesis. Mol Cell Biol 27:7018-7027

Windle JJ, Sollner-Webb B (1986) Two distant and precisely positioned domains promote transcription of Xenopus laevis rRNA genes: analysis with linker-scanning mutants. Mol Cell Biol 6:4585-4593

Xie W, O'Mahony DJ, Smith SD, Lowe D, Rothblum LI (1992) Analysis of the rat ribosomal DNA promoter: characterization of linker-scanning mutants and of the binding of UBF. Nucleic Acids Res 20:1587-1592

Yang MR, Lee SR, Oh W, Lee EW, Yeh JY, Nah JJ, Joo YS, Shin J, Lee HW, Pyo S, Song J (2007) West Nile virus capsid protein induces p53-mediated apoptosis via the sequestration of HDM2 to the nucleolus. Cell Microbiol (in press) 
Yuan TT, Sahu GK, Whitehead WE, Greenberg R, Shih C (1999a) The mechanism of an immature secretion phenotype of a highly frequent naturally occurring missense mutation at codon 97 of human hepatitis B virus core antigen. J Virol 73:5731-5740

Yuan TT, Tai PC, Shih C (1999b) Subtype-independent immature secretion and subtype-dependent replication deficiency of a highly frequent, naturally occurring mutation of human hepatitis B virus core antigen. J Virol 73:10122-10128

Yuan X, Zhao J, Zentgraf H, Hoffmann-Rohrer U, Grummt I (2002) Multiple interactions between RNA polymerase I, TIF-IA and $\mathrm{TAF}(\mathrm{I})$ subunits regulate preinitiation complex assembly at the ribosomal gene promoter. EMBO Rep 3:1082-1087

Yuan X, Feng W, Imhof A, Grummt I, Zhou Y (2007) Activation of RNA polymerase I transcription by cockayne syndrome group B protein and histone methyltransferase G9a. Mol Cell 27:585-595
Zhai W, Comai L (1999) A kinase activity associated with simian virus 40 large $\mathrm{T}$ antigen phosphorylates upstream binding factor (UBF) and promotes formation of a stable initiation complex between UBF and SL1. Mol Cell Biol 19:2791-2802

Zhang L-F, Huynh KD, Lee JT (2007a) Perinucleolar targeting of the inactive $\mathrm{X}$ during $\mathrm{S}$ phase: evidence for a role in the maintenance of silencing. Cell 129:693-706

Zhang S, Wang J, Tseng H (2007b) Basonuclin regulates a subset of ribosomal RNA genes in HaCaT cells. PloS ONE 2:e902

Zhao J, Yuan X, Frodin M, Grummt I (2003) ERK-dependent phosphorylation of the transcription initiation factor TIF-IA is required for RNA polymerase I transcription and cell growth. Mol Cell 11:405-413

Zomerdijk JC, Beckmann H, Comai L, Tjian R (1994) Assembly of transcriptionally active RNA polymerase I initiation factor SL1 from recombinant subunits. Science 266:2015-2018 